\title{
INTRODUCTION: \\ REVIEW SYMPOSIUM ON VIVEK CHIBBER'S POSTCOLONIAL THEORY AND THE SPECTER OF CAPITAL
}

\author{
Ho-fung Hung \\ Department of Sociology \\ Johns Hopkins University \\ hofung@jhu.edu
}

Without any doubt, Vivek Chibber's Postcolonial Theory and the Specter of Capital is a bomb. Through the critique of the foundational works of the Indian Subaltern Studies group, Chibber's questioning pierces right into the anti-universalism core of Subaltern Studies and the postcolonial enterprise. Focusing on the historically and empirically grounded works of Ranajit Guha and Dipesh Chakrabarty, Chibber juxtaposes their interpretation of European and Indian histories to his own interpretation, claiming that their case against Enlightenment universalism was premised on erroneous historiography.

In this symposium, I put together five commentaries on The Specter of Capital from diverse disciplinary and geographical perspectives, together with Chibber's response. The debate between Chibber and the defenders of postcolonialism is too important to be confined to scholars concerned about the future of postcolonialism as a fashionable paradigm in certain humanities and social science disciplines. This debate is, in fact, a continuation of the long-drawn debate between the Marxists and post-structuralists, or the modernists and the postmodernists. It is also closely connected to the future of progressive politics in the global North and South.

While Foucault and many poststructuralists accused the universal rationalism of Enlightenment in Europe of fostering many disasters and massacres in the twentieth century, Habermas (1981) asserts that the poststructuralist forfeit of universal rationalism, as well as the poststructuralist prioritization of the aesthetics and the particular, is conducive to fascist politics. It is noteworthy that Foucault, in the last years of his life, had become an admirer of Khomeini's Iranian Revolution (Afary and Anderson 2005). It is equally not surprising that many statist and ultra-nationalist intellectuals in today's China can comfortably combine the views of Foucault, Edward Said, and Carl Schmidt (as the Nazi legal theorist and the "crown jurist of the Third Reich") in their defense of Third World authoritarianism against the "Western hegemonic ideology" of bourgeois democracy.

The discussion in this symposium focuses on the historiography and theoretical issues raised by The Specter of Capital. The epistemological and ontological clarification in this symposium will help build a foundation for our deliberation on the political - how should public intellectuals choose between uncompromising universalism and uncompromising particularism, and if so, what kinds of universalism and particularism? Is there any virtue and possibility in looking for a middle ground? These questions are of utmost importance for those of us who see theory as not only a tool for understanding the world, but also one for changing it.

\section{References}

Habermas, J. 1981. "Modernity: An Incomplete Project." New German Critique 22: 3-15. Ajary, J. and K. Anderson. 2005. Foucault and the Iranian Revolution: Gender and the Seduction of Islamism. Chicago: Chicago University Press. 


\title{
ON THE ARTICULATION OF MARXIST AND NON-MARXIST THEORY IN COLONIAL HISTORIOGRAPHY
}

\author{
George Steinmetz \\ Department of Sociology \\ University of Michigan \\ geostein@umich.edu
}

Postcolonial Theory and the Specter of Capital is an important book on a topic of major importance for all of the human and social sciences. The book's implications reach far beyond Chibber's critique of subaltern studies, which is his most obvious focus. Chibber's overarching argument is twofold: capitalism does universalize itself to the colonial and postcolonial world, but at the same time, capitalism does not permeate or encompass all other aspects of social practice. As it stands, this is already an important argument for social theory generally and not just for analysts working on former colonies like India. The crisis of what used to be called western Marxism led to two main responses among Marxists. While many simply abandoned Marxism, becoming "post-Marxist," the autonomy of any social practices from capitalism. ${ }^{2}$ Chibber's position is closer to the more nuanced positions of the "regulationist" school; ${ }^{3}$ it is also compatible with a neo-historicist critical realism ${ }^{4}$ that combines an ontology of emergent causal powers with an anti-essentialist epistemology according to which historically varying conjunctures of causal mechanisms interact in contingent, often unpredictable ways to produce empirical events. The fact that Chibber's book's packaging suggests an all-out assault on anyone who would dare to deviate Marxist orthodoxy does not square with the actual content of the book.

Chibber's book is also framed as a critique of Subaltern colonial historiography. Here again, the book's framing does not provide an accurate sense of the directions in which Chibber's thinking takes him. Many of Chibber's specific arguments are broadly consistent with the path-breaking work of the founder of Subaltern Studies, Ranajit Guha.

\section{Chibber's argument restated}

Chibber's book is presented as a critique of postcolonial theory. This is very misleading. The leading postcolonial theorists, including Edward Said (1978, 1993), Gayatri Spivak (1988, 1998), Homi Bhabha (1994), and Leela Gandhi (2006), are barely mentioned here. ${ }^{5}$ Also missing are postcolonial theory's adopted predecessors, such W.E.B. Du Bois, Frantz Fanon, Aimé Césaire and Albert Memmi, or its philosophical antecedents, including Hegel, Nietzsche, Freud, and Heidegger. Postcolonial theory started and remains most firmly embedded in the humanities,

\footnotetext{
${ }^{1}$ E.g. Laclau, E. \& Mouffe, C. 1985. Hegemony and Socialist Strategy: Towards a Radical Democratic Politics. Verso, London.

${ }^{2}$ E.g. Postone, M. 1993. Time, Labor and Social Domination: A Reinterpretation of Marx's Critical Theory. New York: Cambridge University Press.

${ }^{3}$ E.g. Jessop, R. 2008. “Zur Relevanz von Luhmanns Staatstheorie und von Laclau und Mouffes Diskursanalyse für die Weiterentwicklung der marxistischen Staatstheorie" in Joachim Hirsch, John Kannakulam, and Jens Wissel, eds., Der Staat der bürgerlichen Gesellschaft. (Frankfurt: Nomos), pp. 157-179.

${ }^{4}$ On neo-historicist social epistemology see my "Charles Tilly, historicism, and the critical realist philosophy of science," American Sociologist 41, 4 (2010), pp. 312-336; on critical realism in this context see my "Critical Realism and Historical Sociology," Comparative Studies in Society and History 40, 1 (1998), pp. 170-186.

${ }^{5}$ For an excellent overview see Gandhi (1998).
} 
not the social sciences or history. The two main strands of postcolonial theory have focused on questions of the colonial presence within ostensibly noncolonial cultural texts and practices, on the ambivalences of colonized subjectivity and colonial forms of rule, and on the ways colonizing ideas have prepared the ground for conquest and foreign rule. None of these themes shows up in Chibber's book (Steinmetz 2006). Instead the book's exclusive focus is the Subaltern School of history, which has very different origins even if there has been a subsequent rapprochement. A more accurate title for this book would be something like The Subaltern School of History and the Specter of Capital.

That said, Chibber does make a highly coherent argument, one that can be restated in four main theses:

1. Capitalism universalizes itself both geospatially and within a given social formation.

2. Capitalism is entirely compatible with political despotism, labor coercion, and the production and reproduction of cultural difference and diversity.

3. Although capital may "spread[] to all corners of the world, ... this does not mean that it manages to subordinate all social relations to its particular rules of reproduction" ( $p$. 217).

4. Although "it is surely problematic to see capital lurking behind every social phenomenon," it is no less problematic "to deny its salience when it is in fact a relevant causal agent" (p. 123).

\section{Chibber's analysis of the Subaltern School}

In addition to these general theoretical arguments, Chibber shows that there are three key arenas in which the Subaltern School claims that Indian history differs from Western history: First, they claim that the Indian bourgeoisie failed to become hegemonic; Second, they argue for a unique form of "power relations" in India; and, Third, they argue that India has a unique "political psychology." There are three main historians under discussion here: Ranajit Guha, Partha Chatterjee, and Dipesh Chakrabarty. In this section I will present these three main clusters of ideas and arguments.

\section{Capital's mythical universalizing mission}

The first argument, associated with R. Guha, is that capital abandoned its putative universalizing hegemonic mission in colonial and postcolonial India. Chibber counters that the bourgeoisie is not inherently liberal or modernizing and that capitalism is not the same thing as political and cultural modernization. Since the two key comparison cases for Guha, Britain and France, did not really have bourgeois revolutions of the idealized sort there is no reason we should expect India to have had them. Indeed, Chibber continues, cultural and political forms of modernization were in some respects more readily forthcoming after the relevant comparable revolution, decolonization, in India than in Western Europe,

This is a very familiar debate for a German historian. The thesis of the German Sonderweg, or special path to modernity, asked why Nazism came to power in Germany and not in other advanced industrial countries. The basic answer focused on the deviation of Germany's developmental path from its Western neighbors. German history was seen as having been pushed repeatedly in destructive and anti-democratic directions by a clash between economic modernity and political and cultural backwardness, and this structural disjuncture resulted from the fact that German bourgeois liberalism was underdeveloped in comparison with Britain and France. Like the Indian bourgeoisie, the German bourgeoisie was said to have failed repeatedly to take the 
lead in promoting its supposed class interest in liberal democracy, in leading other classes toward that goal. Like the Indian bourgeoisie it failed to suppress the neo-feudal landed nobility, which continued to wield undue influence in politics and culture well into the twentieth century. Another feature of this condition was the so-called "feudalization of the bourgeoisie," the spread of anti-modern cultural values such as conservative anti-capitalism, anti-urbanism, and "cultural pessimism," and a non-hegemonic tendency to resort to state violence that is extremely reminiscent of Guha's diagnosis of the Indian condition. ${ }^{6}$ Guha was relying on a version of Marxist political theory and German history that was demolished by the critics of the Sonderweg thesis. Chibber argues convincingly that real capitalism is compatible with a whole range of non-democratic political and cultural conditions, and that there is no normal set of accompaniments to the spread of capitalism. No historian of fascist Europe, Assad's Syria, or contemporary China should raise an eyebrow at this claim nowadays.

\section{Labor discipline, abstract labor, and cultural homogenization}

Chibber argues secondly that capitalism is compatible with physical coercion at the point of production and that that it produces and reproduces cultural heterogeneity (or "concrete identities") among its workers rather that necessarily pushing toward their homogenization. "It is rational for capitalists to dominate labor" in ways that reach far beyond the autonomic, "dull compulsion of economic relations," as long as violence promises profits (p. 112, p. 123). In the West as in the East, capitalism has always relied on physical as well as symbolic domination (p. $123)^{7}$

Chibber also criticizes the idea that abstract labor leads to cultural homogenization, showing how some postcolonial theorists have conflated these two ideas. "Abstract labor comes clothed in concrete identities," Chibber concludes (p. 144). Capitalism therefore does not have to dissolve social difference. Even deskilling is not inevitable (pace Braverman 1974): new technologies continually generate new skills, even as old industries may suffer from deskilling.

\section{History I and History II}

My favorite section of the book is the discussion of Chakrabarty's (2000) Provincializing Europe and its critique of Chakrabarty's concepts of History 1 and History 2 . History 1 is the history of modern capital, while History 2 consists of all of the multiple, incommensurable histories that develop according to their own specific logics. Chakrabarty's implication is that Marxism would collapse all of the multiple histories of different practices into Capital, even though this is true of only the most totalizing, reductionist forms of Marxism. As Chibber notes, "it is surely problematic to see capital lurking behind every social phenomenon" (p. 123). Chibber argues that the "continued salience of archaic power relations, the resort to traditional symbols, the resilience of caste and kin-based political relations, and so forth--all this can be

\footnotetext{
${ }^{6}$ David Blackbourn and Geoff Eley, The Peculiarities of German History (New York: Oxford University Press, 1985). Lukács (1973: 41) claimed that the German bourgeoisie from the sixteenth-century onward was "characterized by a servility, pettiness, baseness, and miserabilism" which distinguished it from other European bourgeoisies. See George Steinmetz, "German Exceptionalism and the Origins of Nazism: The Career of a Concept," in Ian Kershaw and Moshe Lewin, eds., Stalinism and Nazism: Dictatorships in Comparison (Cambridge: Cambridge University Press, 1997), pp. 251-284.

${ }^{7}$ A similar criticism can be made of Bourdieu's state theory, which twists the stick too far in the direction of symbolic domination. Pierre Bourdieu, Sur l'état. Cours au Collège de France 1989-1992 (Paris: Seuil, 2012); see George Steinmetz, "État-mort, État-fort, État-empire," Actes de la recherche en sciences sociales 201 (2014), pp. 112-119.
} 
shown to be consistent with the universalizing tendency" of capital (p. 125). When Chibber says a practice is "consistent" this does not mean it is entirely subordinated to or determined by capital.

Chibber summarizes his argument against Chakrabarty in four main points:

(1) The sheer existence of "History 2" does not mean that capital's universalization (as defined here) is incomplete (p. 224).

(2) History 2 is not necessarily the main barrier to History 1, and capitalism may be modified by History 2 in ways that are not "type-transforming" (p. 226).

(3) Instead, History 1 itself is the main barrier to History 1 (p. 230), or in Marx's words, the "true barrier to capitalist production is capital itself" -- due to capitalism's logics of competition and crisis. Workers will always tend to come into conflict with the logic of capital accumulation. This opposition to capitalism within capitalism itself is "the only real source of opposition to capital's universalization" (p. 233).

(4) There is no necessary antagonism between History 1 and 2 (p. 233). The "ensemble of social relations in any region need not be subsumed under one set of rules," and the various practices that comprise the whole can be governed by very dissimilar logics, even as capital universalizes (p. 239).

\section{Six Critiques of Chibber}

First, in what is overall an admirably clear and sharply argued book there is a key ambiguity around the question of social crisis or breakdown. If History 1 does not constitute the whole of the society, as Chibber has allowed, why can't there by instability and breakdown in the rest of society (lumped under History 2)? Some examples of instability and breakdown include the death of states, the breakdown of law and order, warfare, terrorism, dictatorship, fascism, and the demise of entire institutions and fields. Fixated as he is on History 1 and the polemic against Subaltern Studies, Chibber doesn't pursue his criticism of one of the weakest points in Chakrabarty's sociology, his lumping of everything but capitalism into a single residual category. Marxism already had a more sophisticated sociology than this in the early 1960s, when Althusser reframed the social totality as a loose congeries of relatively autonomous levels, or ten years later when Bourdieu reframed social space in terms of the field of power and a multiplicity of relatively autonomous fields, each one irreducible to the others. ${ }^{8}$

Second, contingency is not the opposite of causal determinism. The idea of conjunctural contingent causality is completely compatible with the approach Chibber has sketched out. If Marxism is construed as a set of underlying powers, tendencies, and structures, then these will combine in contingent ways with one another and with additional causal mechanisms not theorized by Marxism in producing empirical events. Indeed, Marx's own theory of economic crisis takes this form. There is nothing "fashionable" about the concept of contingency; it is an ontological fact of life in all open systems, natural and social. Repeated patterns or regularities that persist over time and generalize across space are the truly puzzling anomalies.

Third, Chibber raises the question of the limits of compatibility between History 1 and History 2 , but he does not take the next step to ask which cultural and political forms might be incompatible with capitalism. Presumably he thinks this varies historically. But I am not sure. This topic, once a mainstay of Marxist social theory, needs to be revisited.

\footnotetext{
${ }^{8}$ Bourdieu "Séminaires sur le concept de champ, 1972-1975," Actes de la recherche en sciences sociales 200 (2013), pp. 4-37.
} 
Fourth, the only weak part of Chibber's book concerns the topic of rationality and "political psychology." Guha claimed that the specific forms of colonial rule led to a bifurcartion between cultures and repertoires of peasant mobilization and standard modern forms of politics. Chibber's main discomfort with this line of thought has mainly to do with theories of human culture and subjectivity that take seriously the idea that there are multiple forms of rationality-including irrationality--and that motivations are unconscious as well as conscious. These arguments are by no means limited to Subaltern Studies but are in fact one massive alternative pole to Chibber's rationalism in the human sciences. Indeed, sociology even in the United States has tended to lean in the opposite direction from Chibber. Marxism has made alliances with psychoanalysis for a century. There is no inherent connection between the idea of multiple forms of rationality or subjectivity and postcolonial theory.

I don't want to say more about this because I think this argument about rationality is not a necessary part of Chibber's arguments about the nature of capitalism. All of Chibber's arguments about the universalization of capital and its compatibility with non-modern or non-liberal forms of culture and politics are compatible with a less rigid model of culture and psychology. Chibber accuses Chatterjee of harboring a neo-Orientalist vision of the Indian peasant, but the supposed irrationalities of the Indian peasant are easily matched by comparable phenomena in Europe. After all, Freud demonstrated pervasive psychic irrationality at the heart of civilized Europe, and his analysis was proven correct not by the events of the $20^{\text {th }}$ century but by current evidence in biological and neurological psychology for the existence of unconscious and irrational mental processes. 9

In a way this argument doesn't even hinge on the existence of irrational motives but on the very existence of meaning and culture. Chibber is fighting a battle on his own terrain of sociology in the guise of a critique of postcolonial theory. But all serious versions of sociology and philosophy of social science agree that causal mechanisms or causal powers in the social sciences are inherently meaningful or invested with cultural meaning. In the social sciences we have theories of unconscious habitual action generated by something like a habitus. If we adopt instead the language of Weber we could say that there is a multiplicity of ultimate value orientations. Chibber is implicitly defending an entirely unrealistic vision of man as a rational machine.

A fifth point relates to what Chibber calls political form. Oddly, the discussion of political form focuses mainly on the labor process. There is no discussion of the political forms proper in colonial societies - states and empires. And this arena of politics in the narrower sense is one where Chatterjeee's analysis has been of exemplary importance. Chibber ignores the ways in which colonial states preserved or created political forms such as tribes, Princely States, and other indirect rulers, putting limited power in the hands of colonized leaders. Mamdani (1996) argues that the system of Indirect Rule increased levels of coercion in colonial states while limiting the spread of capitalist universalism - not because of the lack of political liberalism but literally by limiting the spread of capitalist economic forms. The "compulsions of market dependence" were sometimes actively suppressed by colonial policies, from British Tanganyika

\footnotetext{
${ }^{9}$ Kent C. Berridge and Piotr Winkielman, "What is an Unconscious Emotion? (The Case for Unconscious Liking)," Cognition and Emotion 17, 2 (2000), pp. 181-211; Kent C. Berridge, "Pleasure, Unconscious Affect and Irrational Desire," in A.S.R. Manstead, N.H. Frijda, \& A.H. Fischer, eds., Feelings and Emotions: The Amsterdam Symposium (New York: Cambridge University Press, 2004), pp. 43-62; and Piotr Winkielman and Kent C. Berridge,

"Unconscious Emotion," Current Directions in Psychological Sciences 13, 3 (2004), pp. 120-123.
} 
and Cameroon South Africa to German Polynesia. ${ }^{10}$ To put it in more concrete terms: by placing local political power in the hands of chosen tribal leaders, weren't colonial governments in fact doing something quite different from what governments were doing inside Europe in the $19^{\text {th }}$ and $20^{\text {th }}$ centuries? It is as if European revolutions actively propped up the most backwards sectors of the non-capitalist feudal classes. In other words it is not correct that the "continued salience of archaic power relations and so on ... can be shown to be consistent with the universalizing tendency" (p. 125) of capital in all times and places. Some "archaic" modes of life were preserved in ways that were antithetical to capitalism's expansion. I am not talking about capitalists using traditional ideologies to dominate their workers, but about colonial states withdrawing potential laborers from capitalist labor markets altogether - literally limiting the spread of capitalist economic forms.

Sixth, Chibber sometimes mirrors the postcolonial terminology he is rejecting. For example, for Chibber Marx is an "Enlightenment thinker" (p. 227). But Marx is more than an Enlightenment thinker. He is also a $19^{\text {th }}$ century social theorist writing in the wake of Hegelian idealism and Romanticism and preserving some aspects of that very different formation. Talcott Parsons, who had studied with Alfred Weber, recognized this, writing that "Marx considered capitalism a definite and specific system of economic organization, marked off sharply in principle from its predecessor and successor in the dialectical process" (1934: 446). Reducing Marx to an Enlightenment thinker is as much of a distortion as Chakrabarty's definition of Historicism as a universalizing teleological social theory, which mirrors Popper's misleading definition. In $19^{\text {th }}$ century Germany, from Savigny to Ranke, and on to Mannheim, Troeltsch, and Meinecke in the $20^{\text {th }}$, Historicism meant almost precisely the opposite of what Popper said it did, signaling an emphasis on the unique, singular, non-repeated and unprecedented-on the "historical individual," as Rickert and Weber called it.

\section{Conclusion}

Postcolonial Theory and the Specter of Capital is a highly stimulating book that not only points out some of the analytic and theoretical deficiencies in Subaltern History but also presents a lucid and refreshing take on some classic Marxist issues. Chibber shows how Marx's model of capitalism's universalization can be combined with recognition of the autonomy of many realms of social life from that relentless process. The articulation of Marxism as a regional theory of capitalism with equally autonomous theories of cultural, political, social, and psychic processes is a promising path for the historical social sciences.

\footnotetext{
${ }^{10}$ I provide evidence of efforts to limit capital's universalization in various colonial contexts in The Devil's Handwriting: Precoloniality and the German Colonial State in Qingdao, Samoa, and Southwest Africa (Chicago: University of Chicago Press, 2007). The British and French colonial development policies after WWII were the result of a particular political-economic conjuncture and cannot be seen as the inevitable breakthrough of capital exerting its universalizing power. Frederick Cooper, Decolonization and African Society (Cambridge: Cambridge University Press, 1996).
} 


\section{References}

Bhabha, H. 1994. The Location of Culture. London and New York: Routledge.

Braverman, H. 1974. Labor and Monopoly Capital. The Degradation of Work in the Twentieth Century. New York: Monthly Review Press.

Chakrabarty, D. 2000. Provincializing Europe. Princeton: Princeton University Press.

Gandhi, L. 2006. Affective Communities: Anti-Colonial Thought, Fin-de-Siècle Radicalism, and the Politics of Friendship. Durham, NC: Duke University Press

------. 1998. Postcolonial Theory. New York: Columbia University Press.

Lukács, G. 1973 [1954] Die Zerstörung der Vernunft, vol. 1. Darmstadt: Luchterhand.

Mamdani, M. 1996. Citizen and Subject: Contemporary Africa and the Legacy of Late Colonialism. Princeton: Princeton University Press.

Parsons, T. 1934. "Sociological Elements of Economic Thought." The Quarterly Journal of Economics 49(3): 511-545.

Said, E. 1978. Orientalism. New York: Vintage.

-----. 1993. Culture and Imperialism. New York: Knopf.

Spivak, G. "Can the Subaltern Speak?" 1998. Pp. 271-316 in C. Nelson and L. Grossberg, eds., Marxism and the Interpretation of Culture. London: Macmillan.

------. 1988. In Other Worlds. New York: Routledge.

Steinmetz, G. 2006. "Decolonizing German Theory: An Introduction." Postcolonial Studies 9(1): 3-13. 


\section{BACK TO BASICS? THE RECURRENCE OF THE SAME IN VIVEK CHIBBER'S POSTCOLONIAL THEORY AND THE SPECTER OF CAPITAL}

\section{Bruce Cumings}

Department of History

University of Chicago

Rufus88@uchicago.edu

"Orient and Occident are chalk-lines drawn before us to fool our timidity."

Nietzsche

I have to begin with a disclaimer: I have never been much interested in postcolonialism. Several reasons explain my inattention, and thus my ignorance: first, even though South Asian studies and East Asian studies are joined in scholarly communion (the Association for Asian Studies) and have in common a flagship journal (the Journal of Asian Studies), rarely do we read each other's work - indeed I know much less about South Asia than I do about, say, Latin America, not to mention Europe or the United States. An aggravating element is that so much of "Asian studies" really connotes country studies, given linguistic hurdles that scholars need to jump over to be taken seriously. Second, attempts to reinterpret East Asian history through the lenses of postcolonial theory are few and far between, probably because its most formidable capitalist and imperial power-Japan - has been an avatar of rapid state-planned, architectonic industrialization for well over a century, and both Koreas, Taiwan and China have followed suit. Third, when I did encounter postcolonial scholarship, it was often in a dense, jargon-ridden, impenetrable form (e.g. Homi Bhabha's work), suggesting to me that I might need a second life to master this literature - or maybe I should just move to a different planet. (The exception would be the clarity and brilliance of Dipesh Chakrabarty's work, which I discovered by becoming friends with him.) Last, nothing they or anyone else have written has dissuaded me from a structural perspective - from what they would call "totalizing" theory - in spite of my admiration for the work of Friedrich Nietzsche, Michel Foucault and other poststructuralists.

From the perspective of the last point, India never seemed to fit the grand narratives of modernity. A locus classicus for this view would be Barrington Moore's Social Origins of Dictatorship and Democracy, which spells out three routes to modernity: the liberal, the state-led (or fascist), and the peasant revolution (or communist) route. India conforms to none of these trajectories, and so in his chapter on India, Moore homes in on the idiosyncratic to explain this exception to his rules: religion, ethnicity, caste, i.e., precisely the difference that appears in Chakrabarty's work. (A less kind take on this difference would be Immanuel Wallerstein's essay, "Does India Exist?") Here was a clear goad to scholars of South Asia somehow to explain this aporia, of appearing to stand aside rather than astride the sweep of modern history. So they girded their loins and produced the Subaltern school and postcolonialism-throwing sand in the eyes of all the great modern theories. Their timing was excellent, because if we identify Barrington Moore with the ' $60 \mathrm{~s}$, Wallerstein with the $70 \mathrm{~s}$, and Marxism with the modern world from 1848 to 1989, a sudden opening came in the wake of "a period of massive defeats for the Left, all across the world" (Chibber 2013: 295). Or as Ron Inden put it, "Indians are, for perhaps the first time since colonization, showing sustained signs of reappropriating the capacity to represent themselves" (quoted on p. 8).

It follows that there is much for me to like in Vivek Chibber's important book. It rehabilitates a convincing structural perspective, whether in Marxist or liberal form, and unlike 
Moore, provides much evidence that India is not so idiosyncratic after all. I am not in a position to judge his empirical comments on, say, Indian labor, since I have not read Chakrabarty's study of jute workers and therefore have little basis for assessing Chibber's critique. But his analysis of the English and French revolutions struck me as cogent; indeed an important theme runs through the book, namely that the bourgeoisie can be progressive and even revolutionary in seeking its own political rights, but generally resists popular or mass movements by other classes to gain the same (e.g. p. 87). He cites the important study by Stephens, Rueschemeyer, and Stephens (1992) Capitalist Development and Democracy, to argue that the same sequence is visible is Latin American cases of democratization $(147 \mathrm{n})$, and I would say the same about recent democratizations in South Korea, Taiwan, and the stark case of China-presumably a communist country where an enormous middle class is a good bit more intent on its own interests and rights than on coalescing with disenfranchised workers lacking unions, let alone with a few hundred million peasants in the countryside. Chibber is right that global capital is entirely compatible with a variety of repressive regimes.

Chibber's critique of Ranajit Guha's (1998) Dominance without Hegemony strikes me as similarly persuasive, at least at the level of how one defines hegemony. Hegemony for Guha means that a ruling class relies less on coercion than on consent, and thereby is able to speak "for all of society" (p. 35). Derived in part from Gramsci, the definition ignores Gramsci's actual situation: sitting in prison in an Italy overtaken by fascism and heavily reliant on coercion. Gramsci meant by hegemony something like the ether that surrounds us, the air we breathe; we do not so much consent to the way in which we are governed, rather we have imbibed certain social, political and cultural conventions more or less from birth, so that we do what we are supposed to do without having to be told, let alone coerced. This is the most formidable kind of power, and it was what Gramsci meant by hegemony. It could be true in Jeffersonian Virginia, or in North Korea. At a more mundane level, it seems clear that a bourgeoisie, whether Western or not, does not need "the active consent of subaltern groups" (p. 35) to maintain its poweralthough consent is clearly to be preferred.

Chibber is also right that neither Marx nor non-Stalinist Marxists ever assumed that there is a single or universal path toward modernity. He cites Trotsky's theory of uneven and combined development (p. 292), but he could just as easily have recalled Alexander Gerschenkron's non-Marxist analysis of "late" development-namely, that no two industrializations are ever the same, because of idiosyncratic differences in a given country, the timing of "insertion" into competition with previously arrived industrial powers, the opportunity to copy or apply new technologies in pre-industrial settings, and so on. In other words, Gerschenkron found it appropriate to include a host of idiosyncratic differences within his structural theory of industrialization. It is surprising, however, that alongside various golden oldies like Marx, Trotsky, Gramsci and Karl Kautsky, we do not find the names of Karl Polanyi or Immanuel Wallerstein anywhere in this book. This seems to be because Chibber is wedded to a Marxist stance that class struggle is the motive force in history, rather than the circulationist theory found in Polanyi and Wallerstein, namely that capitalism is a system of production for profit in a world market, gaining its initial momentum in the long sixteenth century.

Perhaps the nonappearance of Polanyi and Wallerstein has something to do with another absence: Chibber's book has nary a single mention of the country known as China, yet China's recent experience of hell-bent-for-leather capitalist development is our clearest case of the palpable recurrence of the same-a Chinese version if not of the universalities of capitalism, then at minimum a variant of the state-led industrialization operating in Northeast Asia for at 
least 80 years, migrating from Japan to Korea to Taiwan and thence to China. It would be very hard to transfer postcolonial arguments about culture, difference, and idiosyncrasy to any of these countries, and Chibber's critique of the Subaltern understanding of the historical role of the bourgeoisie seems particularly compelling, because in Northeast Asia this class has been brought into being under state auspices (as has the proletariat). And, of course, it is not at all difficult to imagine Marx grinning broadly as global capitalism "batters down all Chinese walls" (from the Manifesto, of course).

The reason for China's absence, I would guess, is that its trajectory since 1980 cannot be explained by a theory of class conflict. Chakrabarty's judgment that "there was no class in South Asia comparable to the European bourgeoisie" (quoted on p. 13) is equally true of China. Instead the critical moment came in 1978-79, as China's reform program and its insertion into the world economy (connoted as "opening") coincided with the establishment of Sino-American diplomatic relations; here was the clearest possible example of the hegemonic power welcoming a pariah state back into the fold, on the assumption that the world would shake China for many decades to come, not that China would shake the world; sooner or later it would be captured by the gravity of capitalism. ${ }^{1}$

Without belaboring the point, China's experience over the past three decades is entirely compatible with a circulationist conception. I know from many encounters that Wallerstein's theories are considered entirely passé by many prominent social scientists (not to mention being roundly loathed by postcolonial scholars), but I recall sitting on a panel at the 1984 annual meeting of the American Political Science Association, as Wallerstein confidently predicted the demise of Soviet and East European socialism, and a subsequent dependency on unified Germany as the central economic power of Europe. I don't recall that he said anything about China, perhaps because he was also enthralled at the time with the idea that Japan would be the avatar of a $21^{\text {st }}$ century world system centered on the Pacific. He wasn't alone in the latter (failed) prediction, but he was quite alone in his (prescient) projections for central and eastern Europe.

Vivek's book has at its base a rigorous theory, one that I largely agree with, but also a kind of diabolical logic: the Subaltern scholars compare the Indian bourgeoisie to an idealized version of the European bourgeoisie; ergo they are Eurocentric in spite of themselves. If Guha's "heroic bourgeoisie" is a bit hard to swallow, can we also say that Chakrabarty's (2000) Provincializing Europe is similarly blinkered and uncomprehending about European history while simultaneously "relentlessly promot[ing] Eurocentrism" (p. 291)? It would never have occurred to me to say that; instead Chakrabarty's goal is (in Chibber's own words, p. 108) to encourage theories that are "attuned to Indian realities and freed of European assumptions," a new set of categories appropriate to Asian settings. Chakrabarty's sensibility is close to Nietzsche's acerbic reference to "ancient Asia and its protruding little peninsula Europe, which wants by all means to signify as against Asia the "progress of man"" (2002: 48). That is, Asians not only are subjected to centuries of colonialism, they also have to sit by and listen to a "hyperreal" construct - namely endless justifications not only for European progress (and dominance), but also for their own subjugation and inferiority, with their only way out being an imitative approximation of modernity that can never quite match the European example. This dilemma could hardly be greater; one sees it in the world-historical moment of Japan's attempt to strike directly at the West, in wartime debates that H.D. Harootunian (2002) confronts in his masterful book Overcome by Modernity - what would be the meaning of a modernity that has a Japanese essence, one that could overcome the West in every sense of the word? When all is said 
and done, this same problem animates the ruling ideology of North Korea (chuch'e) - the longest-running antagonist of American hegemony in the world.

Unfortunately Chibber's critique of postcolonialism partakes of a similar presumption, one like that of the colonizer: "one cannot adequately criticize a social phenomenon if one systematically misunderstands how it works" (p. 25). In other words the Indian bourgeoisie is not only "mediocre," as Guha says (p. 49), a pale reflection of the European example, but Guha and Chakrabarty don't understand the European version either, and instead end up not only with an inadvertent Eurocentrism, but even imbibe "the Whig theory of history" (pp. 80-81). (After reading that, somehow I expected to read that Guha and Chakrabarty also supported the invasion of Iraq and were bosom buddies of Dick Cheney.) I don't know Guha's work, but this is a preposterous caricature of Chakrabarty's scholarship.

Through a similar sleight-of-hand, Chakrabarty's insistence on difference and its inherent antagonism toward European universals leads him into another dead end, according to Chibber, not to mention a paradoxical reversal: he revives Orientalism - indeed, along with Partha Chatterjee he even revives "nineteenth-century colonial ideology" (p. 176); the Subalternists "promote some of the most objectionable canards that Orientalism ever produced-all in the guise of "High Theory" (p. 206). So does Orientalism connote a set of Western representations of Asia, always with a conscious or subconscious intent to measure its difference and its distance from progressive norms, or is it that Orientalism rears its ugly head whenever an Asian insists that his culture, society, history, etc. do not conform to a Western (liberal or Marxist) model? When Chakrabarty "wants the East to have a history of its own" (p. 212), can we call that Orientalism, or can we see in this a self-conscious determination to write history outside of a dominant Western paradigm? By the same logic, one could label Chibber an Orientalist in his insistence that there is only one, true way to understand the development of the modern world.

In the end we return to Nietzsche's aphorism from the essay "Schopenhauer as Educator": "Orient and Occident are chalk-lines drawn before us to fool our timidity" (1983: 128). Chibber's own subjectivity is betrayed by his insistence on capitalizing "East and West," as if we might easily draw a chalk-line, straight or crooked, between a department store in Tokyo or Paris, or a movie theater in Shanghai or New York. In this he is hardly alone: actually-existing Orientalism still occupies the best (Western) minds. Jurgen Habermas, a person whom you might think would know better, privileges the West as the site of the origin of his "public sphere" and its contemporary problematic, as well as its ultimate redemption. He concluded one of his books on "modernity" with this statement: "Who else but Europe could draw from its own traditions the insight, the energy, the courage of vision-everything that would be necessary to strip from the ... premises of a blind compulsion to system maintenance and system expansion their power to shape our mentality" (1987: 367).

This is by no means an unusual emphasis for Habermas, even if it is unusually blunt; his whole work is imbued with "the claim that the modern West - for all its problems - best embodies" the values of rationality and democracy (White 1995: 9), with a now-evident, nowhidden discourse about modern German history (which I think pushes him toward the privileging of norms of political interaction that emerged in postwar West Germany, but nowhere else in German history), and an apparent utter lack of concern for the non-Western experience, except as a species of occasional counter-hegemonic practice in the "Third World." Thus he shares the same prejudices of his cherished predecessor Max Weber (Habermas is most of all a Weberian), but not Weber's passionate and intelligent comparativist project - and in a time when Weber would certainly recognize his own provincialism, were he still talking about "only in the 
West...." But perhaps we better sample the original Weber, what he said then, since we don't know what he would say now:

Only the occident knows the state in the modern sense, with a professional administration, specialized officialdom, and law based on the concept of citizenship.... Only the occident knows rational law.... Furthermore, only the occident possesses science.... Finally, western civilization is further distinguished from every other by the presence of men with a rational ethic for the conduct of life (1981: 312-14).

When we read this, nothing about the postcolonial turn should be surprising; no wonder they all look for the nearest carpet to gnaw. So should we.

\section{References}

Chakrabarty, D. 2000. Provincializing Europe. Princeton: Princeton University Press.

Guha, R. 1998. Dominance without Hegemony: History and Power in Colonial India. Cambridge: Harvard University Press.

Habermas. J. 1987. The Philosophical Discourse of Modernity, trans. Frederick Lawrence. Cambridge: MIT Press.

Harootunian, H. 2002. Overcome by Modernity: History, Culture, and Community in Interwar Japan. Princeton: Princeton University Press.

Nietzsche, F. 2002. Beyond Good and Evil. New York: Cambridge University Press.

Nietzsche, F. 1983. Untimely Meditations. New York: Cambridge University Press.

Stephens, J., D. Rueschemeyer, and E. Huber Stephens. 1992. Capitalist Development and Democracy. Chicago: University of Chicago Press.

White, S. 1995. "Reason, Modernity and Democracy." Pp. 3-16 in S. White, ed., The Cambridge Companion to Habermas. New York: Cambridge University Press.

Weber, M. 1981. General Economic History, trans. by Frank H. Knight. New Brunswick, NJ: Transaction Books.

\footnotetext{
${ }^{1}$ See my Parallax Visions: Making Sense of American - East Asian Relations (Duke, 2002), chapter six.
} 


\title{
CAPITALIST DEVELOPMENT, STRUCTURAL COSTRAINT AND HUMAN AGENCY IN THE GLOBAL SOUTH: AN APPRECIATION OF VIVEK CHIBBER'S POSTCOLONIAL THEORY AND THE SPECTER OF CAPITAL
}

\author{
Michael Schwartz \\ Department of Sociology \\ Stony Brook University \\ Michael.Schwartz@stonybrook.edu
}

Let me start by saying that my biggest fear is that Post Colonial Theory and the Specter of Capital will be taken at face value: as a systematic and thorough savaging of Subaltern Studies. Unfortunately, it does fit that description quite perfectly. But for me, it is so much more than that, and not even primarily a critique of the currently hegemonic perspective on postcolonial development. Instead, I see it as a modern analog to Engels' Anti-Dühring, which created a kind of negative immortality for Eugen Dühring, now known only through Engels' critique. As Engels said in the introduction to that text, he engaged in such a definitive critique because it "gave me... the opportunity to develop in a positive form my views on questions which are today of wide scientific or practical interest" (1972: 10).

I view Chibber's work as A parallel sort of enterprise. I think the "positive" analysis in Postcolonial Theory - that is, Chibber's both original and synthetic portrait of the role of class dynamics and the logic of accumulation in the evolution of the postcolonial world - is so compelling that it will become foundational for a a rich vein of new scholarship that supplants Subaltern Studies. And - because Chibber, like Engels, has chosen this dialectical format as the vehicle for developing and expressing his viewpoint-he may well confer upon Subaltern Studies a Dühring-like negative immortality. His critique is so devastating that long after the key texts of Subaltern Studies are out of print and out of mind, their ideas will be learned and even memorized by the legion of readers of Postcolonial Theory.

I want in this essay to call out some of the key components of this "positive" analysis and argue for its value, while calling for Chibber and the rest of us to utilize its strengths, correct its inadequacies, and fully develop its potential as a tool for understanding and challenging the negative dynamics of post-colonial capitalism.

Before leaving the Anti-Dühring metaphor, I want to congratulate Chibber on emulating Engels, because the brilliance of this text derives, at least to a considerable degree, from the method of exposition. Each analytic sojourn begins with perfecting the analysis contained in key texts of Subaltern Studies, then moves to a definitive criticism of the perfected argument. During this process, the criticism is leavened by a careful appreciation and absorption of the many positive contributions of postcolonial theorists, with the best elements becoming building blocks for Chibber's (finally delivered) alternate analysis.

The method works beautifully because even brief presentations of the final positive syntheses are instantly grasped and appreciated, because we are attuned - by the detailed scrutiny of the Subalternists - to the key markers that an adequate explanation must address.

But this indisputably productive approach also has its problems, because it often results in a recessive under-emphasis on the dynamic elements in Chibber's perspective. This is particularly visible in the concluding chapter, where he devotes six long pages to reviewing the critique and only one short (though luminous) page to his positive analysis (pp. 286-93 vs. p. 285). 
Let me illustrate what I think is the problem by tracing his analysis of the origins of structural conflict within postcolonial society (see particularly Chapter 9). After deconstructing the Subaltern Studies argument that such conflict resides and emanates from survivals of preexisting formations, Chibber then accepts their claim that these non-capitalist formations play an important role in societal dynamics writ large, while showing that they have not been the locus of anti-capitalist resistance. In his crowning analysis - based on evidence drawn not only from the Subaltern theorists themselves, but also the rest of the post-colonial world, Chibber shows that the big conflicts - those that yield (and threaten to yield) major shifts in post-colonial trajectories - emanate from the contradictions within the sectors of postcolonial society that are most fully absorbed into the process of capital accumulation. In perfecting this negative argument, Chibber actually offers an integration of political economic theorizing around state development and the extensive literature on third world revolution, while absorbing the best elements of subaltern studies.

I want to focus on one key moment in Chibber's argument to point towards what I think is a major area that needs further attention. One of the most compelling passages in the book responds to Partha Chatterjee's analysis of the dynamics of peasant mobilization. Chibber concludes:

Chatterjee maintains that the defining element of Indian peasants' agency is their insulation from "bourgeois consciousness," from strategies that prioritize individual interests. Their self-identities issue from their membership in the community, and their basic motivations derive from their sense of obligation to this community. If this is true, however, surely it should also mitigate the internal class differentiation of the peasantry.... The emerging rich peasants acquired the land because their peers fell on hard times.... The wealthier peasants had a choice: they could assist their fellow villagers out of a sense of duty, as members of the community, without seeking personal gain; or they could take advantage of their peer' misfortune and usurp their land, their most precious resource.... For the class of jotedars to have emerged it must be the case that a section of the smallholder community chose the latter course of action. They chose to pursue their individual interests. In other words, these smallholders acted on precisely the "bourgeois consciousness" that Chatterjee insists they lacked (p.174).

This precise targeting of a key dynamic in the colonial world-the importation of capital accumulation into peasant society and the class differentiation that follows - allows Chibber to demonstrate that rural conflicts were not "conservative" efforts built on the (already fractured) communal solidarity, but rather expressions of the growing class divisions created by the capitalist invasions.

But, at the same time, Chibber rushes past a crucial point what I think emanates from this insight. As he states in other contexts, the old communalism was not obliterated-but instead transmuted - during this process. Such pre-capitalist formations do not disappear; they adapt into the capitalist structure, creating a kind of mutual evolution in which the outcome structure will be unique in each country, and quite different between and within regions (see pp. 132-4). For many pre-capitalist formations, this adaptation has little consequence for the outcome dynamics, but surely this communalism - and the shape of its altered role in the capitalized 
structure - is a causal vector in the resulting class dynamics. Put simply: what becomes of the communalistic ethos that Subaltern Studies valorizes? It arrives in the new formation in a variety of forms, and Chibber (and those of us who take up his argument) must offer an understanding of the dynamics that determine the outcome formation. Even more important is to codify and understand the varying structural trajectories characterizing the various outcome formations.

I want to offer one avenue of analysis regarding the afterlife of communalism in postcolonial society. From Chibber's argument, we see one regularity that occurs wherever rural capital accumulation is set in motion: the creation of self-aggrandizing rich peasants who have abandoned (much of) the communalistic ethos. But what of the poor (and soon becoming landless) peasants? It seems to me that there is considerable work to be done to understand the circumstances under which they abandon the communalistic ethos and organize against the rich peasants, and those circumstances when they continue to embrace communalism and ally themselves with the jotedars (despite their growing contradictions of interest). I am particularly taken by the contrast between, say, Vietnam and China, which had sustained insurrections of peasants against the rural elites, and the American south, where southern tenants most often joined movements led by the same rural elites who had taken their land and/or exploited their labor. For me, we are sorely in need of an analysis that will allow us to understand what sorts of absorption processes - and related dynamics - yield one or another of these modalities. In India, it would appear that both modalities have developed in different regions and different times, and careful scrutiny using Chibber's analytic tools could well unravel this critical dynamic.

The various strands in Chibber's argument are woven together, and much is lost when we disentangle them. But we need to do so anyway, because leaving them undifferentiated conceals some of the most promising yet unexplored insights. Consider, for example, Chibber's treatment of what he calls "the real engine of democratization" (p. 145). Here he begins with the Subaltern Studies assertion that parliamentary democracy (including its essential accoutrements, free speech, equal protection, etc) was an organic expression of the imperatives of capitalism ascending - and that the failure of democracy in the post-colonial world must derive from strong pre-capitalist (and axiomatically anti-democratic) forces. Partly, Chibber rebuts this argument through his savaging of the communalism assertions, but this is only the beginning link in what becomes his broader theory of when and where parliamentary democracy arises.

Herein lies another instance in which Chibber preserves elements of the Subaltern Studies analysis: he endorses the proposition that parliamentary democracy was (and is) a consequence of ascendant capitalism. But he stands their argument on its head. He definitively rebuts their assertion of bourgeois activism, and replaces it with subaltern activism.

To accomplish this inversion, Chibber challenges the Subalternists' core argument that pioneer Western capitalists actively fought for parliamentary democracy and its accompanying rights, as soon as their political power allowed it. He demonstrates instead that the rising bourgeoisie and its political allies in England and France resourcefully opposed democracy; and that the arrival of universal suffrage and the other elements of what we now call democracy were a result of sustained struggle by subaltern classes. But he preserves the connection between capitalism and democratic rights, pointing out that it was only with the rise of industrial production that the working class (in alliance with the other subaltern groupings and in opposition to the capitalists) achieved the leverage it needed to demand and win universal suffrage and the other accoutrements of democracy. He completes this tightly woven argument with a gorgeous little comment: "it was only through subaltern mobilizations that capitalism was civilized "(p. 232). 
But as beautiful as this argument is, I feel it is only a start. There is so much more that needs to be done here. First and foremost, Chibber (and those of us who work with his ideas) must explain why capitalism confers the needed leverage on the subaltern classes. He makes a start by invoking Marx's founding insight that the gathering of industrial workers into close proximity, and engaged in a production process characterized by ever-increasing division of labor, was the foundation for class formation and therefore working class agency. But this is only a beginning.

Second, and perhaps closer to the analysis that Chibber provides, is answering a host of questions around class struggle. As we look from country to country (in the capitalist core or the postcolonial periphery), we find a huge variance in the degree of "democratization." This is especially clear if we shift our attention from contested elections as the sin qua non of "democracy" and focus instead on the full array of political, economic, and human rights that are supposed to be integral to democratic society. Once we do this, we see that there is no facile correlation between the extension of capitalist accumulation into the far corners of society and the further extension of democratic rights. Instead, there are huge and changing differences among countries with comparable levels of capitalist penetration. So we need a much more refined understanding of the dynamics of capitalist development to understand the configurations that create the capacity (and the intention) for subaltern classes to civilize capitalism.

Let me point to one set of elements that must surely be a major factor in unraveling this conundrum: racism and its categorical cousins-patriarchy, religious intolerance, ethnic discrimination, etc. In tracking the successes and failures in civilizing capitalism, we must acknowledge that racism (or any of its cousins) has been a key factor in determining the degree of leverage either available to, or accessible by, subaltern movements. But we must press beyond this proposition to understand when, where, and how the racism process operates-since here too there is great variance in its role, depending on the national or regional setting. There has been some important work on these questions that can be integrated into the Chibberian analysis. One exemplar is Richard Williams' (1990) argument that racism (or any of its cousins) is most impactful in defense of capitalist barbarism when racial categories coincide with occupational stratification, generally yielding meager citizenship rights for the racial minority and degraded rights for the "privileged" "majority."

For me this excursion into the nuts and bolts of elaborating Chibber's analysis leads back to the proposition that capitalism absorbs pre-capitalist formations while preserving and evolving many of the elements. Can we comprehend this absorption process well enough to understand how the distinct dynamics that emerge impact on the trajectory of economic development, the vulnerability of the structure to democratic reform, and the agency of subaltern masses?

Let me turn now to a third (also indelibly interconnected) element of Chibber's analysis: the structural constraints that led Global South nationalists to pursue modernization (instead of other alternatives including socialism). In contrasting his perspective with Partha Chatterjee's argument that these policies were expressions of pro-western sycophantism, he concludes: "Chatterjee's theory of nationalism fails in large measure because it denies the reality of capitalist constraints. It treats rational decisions as having been ideologically driven and, in so doing, vastly exaggerates the role of ideas and grossly undervalues the effects of actually existing structures" (p. 250).

This is yet another of Chibber's insights that emerge from his dialectical method. His assertion of structural constraint is fully persuasive because he has so meticulously demolished 
Chatterjee's assertion that nationalist leaders could have pursued many different development strategies; and thus effectively rebutted his conclusion that modernization policy reflected ideological commitment. But this method of exposition has deprived us of a full treatment of nationalism as an ideology and its role in determining economic and political trajectories. While Chibber's structural argument is compelling, he is inattentive to the impact of nationalism within the structural constraints he so forcefully articulates. I am thinking here that in the Indian case (and many, but not all others), nationalism was instrumental in muting the class struggle or misdirecting subaltern classes away from demands that might have brought them greater citizenship rights or a greater share of the rewards of development.

And then there is the larger question about the diversities in the types and impact of nationalism in differing post-colonial settings. Vietnamese and Indian nationalism would appear to have had very different impacts on anti-colonial struggles and postcolonial development. In explaining this difference, we may well, as Jeffrey Paige (1978) has argued, look to the differing paths of capitalist development as structural determinants that produce different forms of human agency - including different forms of nationalism - and ultimately impact on different development strategies. ${ }^{1}$

I think that Chibber points us toward a comprehensive analysis of these issues in his luminous, but all too short, recapitulation of his "positive account of how capital, power, and agency actually work." The first two of the four basic elements of his "alternative argument" are:

The first is that the universalization of capital is real, pace the claims of the Subalternist collective. The colonies' political dynamics did not attain a fundamentally different kind of modernity than did the Europeans.' More precisely, their modernity may have been different, but not in the ways that postcolonial theory insists. Theirs is a modernity that, over time, became no less reflective of capitalist imperatives than the French or German. The second is that the universalizing drive of capital should not be assumed to homogenize power relations or the social landscape more generally. In fact, capitalism is not only consistent with great heterogeneity and hierarchy, but systematically generates them. Capitalism is perfectly compatible with a highly diverse set of political and cultural formations (p. 285).

But this also points to what might be the least developed component in Chibber's analysis: human agency. He is so occupied with debunking the cultural determinism of the Subaltern School that he does not pay enough attention to the first part of Marx's famous structural axiom, that people "make history, but not as they choose." While Chibber is right to call out the structural dynamics of capitalism that the Subalternists attempt to sweep away, we also need a comprehensive analysis of the circumstances under which people are able to collectively choose and implement progressive social change. We need to identify and comprehend the broader nexus of dynamic forces that facilitate or constrain our efforts to construct what Perry Anderson (1980: 20) has called "a premeditated future."

\footnotetext{
${ }^{1}$ Another building block toward this analysis can be found in Goodwin (2001).
} 


\section{References}

Anderson, p. 1980. Arguments within English Marxism. New York: New Left Books.

Engels, F. 1972. Anti-Dühring [Herr Eugen Dühring's Revolution in Science]. New York: International Publishers.

Goodwin, J. 2001. No Other Way Out: States and Revolutionary Movements, 1945-1991. New York: Cambridge University Press.

Paige, J. 1978. Agrarian Revolution. New York: Free Press.

Williams, R. 1990. Hierarchical Structures and Social Value: The Social Construction of Black and Irish Identities in the U.S. New York: Cambridge University Press. 


\section{ON VIVEK CHIBBER'S POSTCOLONIAL THEORY AND THE SPECTER OF CAPITAL}

William H. Sewell, Jr.

Department of History

University of Chicago

w-sewell@uchicago.edu

Vivek Chibber's Postcolonial Theory and the Specter of Capital is a critique not of postcolonial theory in general, but specifically of the Subaltern Studies School, as represented by Ranajit Guha, Partha Chatterjee, and Dipesh Chakrabarty. The subalterns, of course, have focused specifically on Indian history, a subject with which I have only a passing acquaintance. This means that my comments should surely be taken with a healthy grain of salt.

I suppose I must have been asked to contribute to this symposium to say something about the famous entity called "Europe" that Dipesh Chakrabarty (2000) and other postcolonial theorists have striven to deprovincialize. After all, Europe is the unavoidable "other" against which the subalterns have evaluated Indian history - unavoidable because India was conquered and ruled by Britain for nearly two centuries and because Europe, and more recently an expanded "West" that notably includes the United States, has dominated the world militarily, economically, culturally, and intellectually for the past three hundred years. Chibber, it should be said, doesn't dispute the necessity of thinking about the history of India in comparison with the West; what he disputes is the way the subalterns think about it and the conclusions they draw.

Chibber is not a sympathetic critic: indeed, he's basically hostile to culturalist theories, to postmodern literary and philosophical tropes, and to the murky Hegelian and Heideggerian language that appears in the later work of Dipesh Chakrabarty. Chibber attempts to puncture what he regards as the vague and exaggerated claims of post-colonial theorists and to defend a Marxist version of universal Enlightenment values against what he calls the subalterns' "orientalism." But Chibber doesn't waste time declaiming against the subalterns. Rather, he seriously and painstakingly subjects their arguments to a dissection that is unforgivingly rationalist. In the end, Chibber convinces me that the subalterns' major claims are pretty shaky.

The subalterns' arguments of course evolved over time. Thus Ranajit Guha's Domination without Hegemony (1997), a collection of essays composed in the late 1980s and early 1990s, was written from within a basically Marxist framework whereas Dipesh Chakrabarty's Provincializing Europe (2000) insists on Marxism's essential Eurocentrism and its consequent inability to grasp Indian historical developments. But it is remarkable that from beginning to end the "Europe" that the subalterns grapple with is represented above all by Marxism and by particular Marxist imaginings of European history. This suggests that Subaltern Studies must be understood in part as an ambivalent emanation of a disappointed Marxism, an aftermath, one supposes, of the failed Naxalite movement of the 1970s.

Chibber thinks this disappointment is misplaced, that Marxist analysis retains its utility for understanding economic, social, and political developments both in the "West" and in the developing world. The subalterns' discontents, he argues, arise from both empirical and theoretical errors.

Ranajit Guha, in Domination without Hegemony, argued that much of India's postcolonial misfortune can be traced to the weakness of the Indian bourgeoisie. In Guha's telling, the Indian bourgeoisie failed to live up to the heroic legacy of their European counterparts, who, in two great revolutions - in England in the 1640s and in France in 1789 - 
overthrew feudalism and established liberal bourgeois states that fulfilled the universalizing drive of capitalism, both by securing the political dominance of the capitalist class and by fashioning hegemonic political orders that extended political rights to subordinate classes. By contrast, the Indian bourgeoisie, in its would-be revolutionary moment of decolonization, gained political dominance but failed to overthrow feudal relations in the countryside or to establish anything like the genuinely hegemonic political order characteristic of Europe.

I need hardly point out that this portrayal of the English and French revolutions is standard-issue orthodox Marxism - and is by now well past its "sell-by" date. The problem, as Chibber argues, is that this old orthodox Marxist account seriously misunderstands European history. Now, I have to say that Chibber's own grasp of French and English history seems to me a bit shaky. For example, he discusses the English Civil War of the 1640s at some length but doesn't even mention the English Revolution of 1688, which most European historians now alive would regard as having a much better claim to being something like a bourgeois revolution. And he concludes, remarkably, that the contribution of the European revolutions to "the birth of modern liberalism" was "weak"-completely ignoring, for example, such founding liberal moments as the separation of powers instituted in England in 1688 or the French Declaration of the Rights of Man and Citizen of 1789. Nevertheless, Chibber's most important conclusions about the European experience seem to me quite correct: that the regimes put in place in the wake of the so-called bourgeois revolutions actually placed stringent limits on the political participation of popular classes and that democratization in Europe owed far more to struggles from below than to the generosity of the bourgeoisie. This, in turn, implies that the Indian bourgeoisie's failure to embrace an egalitarian order, far from constituting a deviation from the politics of the European bourgeoisie or a failure of capitalism's universalizing dynamic, was instead exactly what the European experience of capitalism and revolution should have led us to expect.

Chibber also strives to refute the essentially parallel argument of Dipesh Chakrabarty's Rethinking Working-Class History. Chakrabarty asserts in this book (originally published in 1989) that the nature of relations between jute mill workers and capitalists in Calcutta — which were based more on personal authority, caste, and religious identities than on the anonymous labor market and class identities-demonstrates that European capitalism's universalizing mission had stalled on Eastern shores. Chibber replies by showing that European and American capitalists have repeatedly relied on personal authority and particularist identities whenever these could produce a tractable labor force. Again, there was nothing "Eastern" about labor relations that took this form nor did they represent any failure of capitalism to universalize itself.

Chibber's arguments in these two cases have perfectly good Marxist credentials. What he shows here and elsewhere in his book is that Marxist empirical and conceptual work on the history of capitalism is perfectly capable of making sense of Indian developments - that there is no fundamental conceptual divide between the history of "Europe" and the history of "the East."

This, of course, puts Chibber strongly at odds with Chakrabarty's arguments in Provincializing Europe, probably the most celebrated (and certainly the most difficult) work of the Subaltern school. Chibber remarks that Chakrabarty, near the beginning of this book, claims that the "Europe" used as a point of comparison for Indian history is a "hyperreal" entity-in Chakrabarty's terms a "metanarrative figure of the imagination" that is "constructed by the tales that both imperialism and nationalism have told the colonized" (2000: 27, 40). Chibber dismisses this claim as a dodge, asserting, quite correctly, that Chakrabarty in fact constantly makes claims about divergences between the real histories of Europe and India. 
However, I think that Chakrabarty's "Europe" actually is hyperreal in a somewhat different sense. It seems to me that Chakrabarty constructs a "Marxism" fused with a hyperreal "Europe" that is very much a "narrative figure of the imagination"-and then proceeds to criticize this construct. (Note that "Europe" for Chakrabarty never connotes such eminently European features as Christian fervor, or royal absolutism, or romanticism, or militarism, or Fascism-only the Enlightenment, democracy, liberalism, rationality, capitalism, and imperialism. Such a one-sided Europe is quite unrecognizable to a Europeanist.) In Provincializing Europe Chakrabarty, on the basis of a rather daunting reading of Marx, claims to find, but I would say constructs, a highly idealized, unified, teleological and (it must be said) undialectical history of capitalism that he labels "History 1," a capitalist history to which "the Enlightenment universals" inhere or that includes within itself "the categories of Enlightenment thought" (2000: 250, 71). Next to this he constructs another history, what he calls "History 2," that contains diverse logics of action and belonging and that is "charged with the function of constantly interrupting the totalizing thrusts of History 1" (2000: 66). It is this History 2 that especially comes into prominence in the East, where capitalism has been more recently introduced. Chakrabarty claims that historians, both Eastern and Western, have been too mesmerized by the perfect unity and self-identity of History 1 and have underplayed the disruptions and incompleteness that History 2 introduces into the history of capitalist societies.

Chibber agrees that one can reasonably distinguish a History 1 that refers to the specific and necessary dynamics of capitalist accumulation from a History 2 that is not fully interior to capital's life process. But Chibber's version of History 1 is rather stripped down: it's not identified with Europe or freighted with necessity or equated with the Enlightenment. On the other hand, it is decidedly dialectical - the capitalist core is full of contradictions that constantly threaten to disrupt any orderly process of accumulation. That is to say, it actually resembles the capitalism that we all know and love. Chibber's History 2, like Chakrabarty's, is defined as those historical forces not constituted by the core of capitalism. But Chibber insists that History 2 normally poses no particular threat to History 1. It's either perfectly compatible with capitalism, as when capitalists take advantage of differences of religion, caste, or race to divide or discipline their work forces. Or it's basically indifferent to capitalism, as when cultural practices of one sort or another go on with no noticeable influence one way or the other on capital accumulation. Aspects of History 2 can, of course, on occasion disrupt History 1, but disruptions from within the logic of History 1 are far more common and far more consequential. For Chibber, there is no reason either to shun History 1 or to exalt History 2. As you may have guessed, I prefer Chibber's version of the two histories to Chakrabarty's.

To sum up: Postcolonial Theory and the Specter of Capital provides a careful, sustained, intelligent, and salutary critique of Subaltern Studies. Its genius is critique, however, rather than reconstruction. Chibber's rationalism, which sometimes gets very close to rational choice, is basically a solvent or a deflator. Chibber has cleared the ground and has usefully indicated the value of Marxist analytical tools. But in my opinion it will take a Marxism more infused with cultural sensitivities to reconstruct a superior history of the postcolonial world.

Let me close with a few final thoughts on the provincialization of Europe. If postcolonial historians really are serious about provincializing Europe, perhaps they should begin by recognizing that Europe is actually divided into many provinces - usually known as nation states - that have surprisingly diverse histories. The histories of politics or thought or industrialization of England, Spain, France, Hungary, Germany, Norway, and Greece are by no means the same. Differences between the histories of Portugal and England may be as great as those between the 
histories of China and France. And the histories of none of these countries are identical to the history of capitalism, or the Enlightenment, or democracy. Perhaps we should try banishing the over-inflated collective noun "Europe" from our vocabularies for a few years and treat that broad peninsula at the western end of Eurasia as what it is: a collection of highly diverse provinces, not some unified totality. Chibber's deflation of post-colonial theory should help to point us in this direction.

\section{References}

Chakrabarty, D. 1989. Rethinking Working-class History: Bengal 1890 to 1940. Princeton: Princeton University Press.

-------. Provincializing Europe: Postcolonial Thought and Historical Difference. Princeton: Princeton University Press.

Guha, R. 1997. Dominance Without Hegemony: History and Power in Colonial India. Cambridge: Harvard University Press. 


\title{
MINDING APPEARANCES: THE LABOR OF REPRESENTATION IN VIVEK CHIBBER'S POSTCOLONIAL THEORY AND THE SPECTER OF CAPITAL
}

\author{
David Pedersen \\ Department of Anthropology \\ University of California-San Diego \\ dpedersen@ucsd.edu
}

"Why is labor represented by the value of its product and labor-time by the magnitude of that value?"

Karl Marx

In the Preface to his Postcolonial Studies and the Specter of Capital, Vivek Chibber (2013: xii) thanks Neil Brenner for the book's name, writing that “... Brenner gets the lion's share of credit for the book's title...the title is basically his." Several scholars have questioned whether the book's primary content, a sustained critique of writings by Ranajit Guha, Partha Chatterjee and Dipesh Chakrabarty, is a fair proxy for the diverse efforts of people who identify themselves as studying or being a part of the "post-colonial." The second part of the title, "Specter of Capital," orients my comments on the book in this essay. It is an accurate choice of terms, because Chibber's book does offer a significant argument about the critical study of appearances, which is a term directly related to the word apparition and its close cousin, specter.

Readers should recognize the word specter as a reference to the opening sentence of Karl Marx and Friederich Engel's "Manifesto of the Communist Party" published in 1848: "A specter is haunting Europe -- the specter of Communism." Readers also will discern that a tradition of Marxism gets a lion's share of credit for informing the book's content. One of the book's primary goals is to refute the claim, attributed by Chibber to the three authors affiliated with "Subaltern Studies," that critical study of capitalism informed by Marxism is not applicable to the postcolonial history of India. The way that the book approaches appearances directly echoes Marx's metaphorical use of specters and ghosts in his varied analyses of capitalist relations. ${ }^{2}$

There are two different connotations to "specter" that make their appearance in Chibber's book. The first is the understanding that beyond or behind a surface level of particular human sentiments, practices and habits, however dominant and durable, lies something more basic and material shared by all individuals in any context. The second perspective on appearances suggested in the book is that particular kinds of representations or mediations may actually become more material, mobile and capable of making things happen in the world. The first modality is about appearances and something behind them. The second approach is about the agency of appearances and their capacity to hide both the conditions that give rise to them and their manner of contributing to perpetuating these same conditions. This essay focuses on these

\footnotetext{
${ }^{1}$ See the review by Bruce Robbins of Columbia University, "Subaltern-speak," in the journal $n+1$, issue 18, March 2013 and the on-line post by Chris Taylor of University of Chicago http://clrjames.blogspot.com/2013/04/not-evenmarxist-on-vivek-chibbers.html.

${ }^{2}$ On the significance of "specters" with respect to both the figure of Marx and his work, see Jacques Derrida's (1995) Specters of Marx: The State of the Debt, the work of Mourning and the New International, delivered in 1993 as the plenary address for a conference at the University of California-Riverside's Center for Ideas and Society. Nine critical commentaries on the book and Derrida's response to them are collected in Ghostly Demarcations: $A$ Symposium on Jacques Derrida's Specters of Marx, edited by the late Michael Sprinker (2008).
} 
two understandings of appearances and the way that the book's manner of minding them is integral to its critical analysis. I am less concerned with choosing a side in the academic debate to which the book substantially contributes than to use its appearance as an opportunity to push forward discussion about how better to render fully "explanatory critiques" of capitalist relations anywhere on the planet. ${ }^{3}$

\section{India and Europe}

Postcolonial Theory and the Specter of Capital is organized as an analytical critique of the writings of Ranajit Guha, Partha Chatterjee and Dipesh Chakrabarty, among the most prominent scholars associated with the Subaltern Studies collective. Chibber focuses on their work and identifies a constellation of arguments that stipulate several key divergences between Indian and European modernity. Chibber distills three themes, pointing out that the authors participate in an aggregate project of arguing for a radical Indian difference regarding: 1) the character of its bourgeoisie; 2) the relative role of distinctly capitalist power relations; and, 3) what Chibber calls the "political psychology" of Indian subaltern actors. Chibber lays out what he understands as the necessary preconditions required for sustaining all the arguments that buttress the claim of a radical India- European divergence along the three thematic axes. He effectively tests to see if these conditions are, in fact, manifest in the evidence and logically plausible. Chapter by chapter, he endeavors to show how the evidentiary premises of the arguments in favor of the three distinctions cannot be sustained.

Chibber also specifies an alternative interpretation and approach meant to overcome the stark India/European divide, allowing for variation within what is understood as a unitary capitalism, marked by two fundamental tendencies. The first is that capitalists tend to spread and deepen their activities as a feature of their recognition of the requirements of the system in which they participate. The second is that workers, as they experience forms of exploitation through the actions of capitalists, will be inclined to resist this process, motivated by recognition of direct threats to their material or bodily well-being. Chibber calls these "Enlightenment" universal tendencies and he wishes to defend them against the claim by Subaltern Studies authors that they are not applicable to Indian history. In this defense lies the book's first critical approach to appearances.

\section{Ghostbuster}

Postcolonial Theory and the Specter of Capital carries a definition of one domain of social life that is understood as separate and distinct from an underlying and more basic reality. In the author's terms, all of these surface aspects or features fall under the umbrella term of "political psychology." Chibber does not explain this expression, though it has a substantial scholarly pedigree, including its early appearance in the German ethnologist Adolph Bastian's 1860 book, Man in History (Koepping 2005). Bastian's work influenced the famous British anthropologist, Edward B. Tylor and also directly shaped the scholarship of Franz Boas, known as the founder of US anthropology (Stocking 1984: 14). ${ }^{4}$ It also is associated with the work of U.S. political scientist Harold Lasswell during the 1930s and 1940s (Ascher and Barbara Hirschfelder-Ascher

\footnotetext{
${ }^{3}$ I borrow this term from Roy Bhaskar (1986) as way to refer to the combined task of explaining the workings of capitalism and the falsity of its necessary self-representation.

${ }^{4}$ Bastian was Boas's senior advisor at the Ethnographic Museum in Berlin.
} 
2003) Chibber deploys political psychology as a general hypernym for what he identifies elsewhere in the text as consciousness, culture, identity, ideology and religion. ${ }^{5}$

Chibber invokes all five of these concepts especially in chapters 6-8, making this part of the book the most concentrated critical examination of how the Subaltern Studies authors treat the content of what Chibber has called "political psychology." He summarizes his interpretation of the Subaltern Studies position in the fourth paragraph of chapter seven: "They deny that agents share a common set of needs or interests across cultural boundaries, arguing instead that the peasants and industrial workers in the East have a wholly different psychology from those in the West" (p. 153). In chapter six, Chibber focuses on Partha Chatterjee's work, which he summarizes as organized around the central claim that "communal norms, not individual interests, were the fount of rural politics" in India (p. 154).

Chibber's critique rests on examining Guha's Elementary Forms, which Chatterjee had drawn upon, as well as Chatterjee's own research on peasants in Bengal and identifying instances where peasants seemed to act according to individual interests rather than shared cultural norms. He focuses on Chatterjee's identification of internal differentiation between a relatively wealthy small-holding fraction, jotedars, who employed workers, obtained rents from tenant farmers and earned income from lending operations, and the majority of peasants who were primarily subsistence farmers. Chibber argues that this apparent diversity refutes Chatterjee's claim that a singular peasant communal ideology dominated Bengali peasant life, fully masking the relative exploitation carried out by jotedars.

In chapter eight, Chibber continues this line of analysis, tracing the relationship between collective norms and individual interests through consideration of Dipesh Chakrabarty's book, Rethinking Working Class History: Bengal 1890-1940. According to Chibber, Chakrabarty "purports to have discovered that subordinate groups are not motivated by a defense of their interests; instead, they are driven by their valuation of community, honor, religion, and other normative ends." Chibber argues against Chakrabarty's claim that Jute workers "remained prisoners of a precapitalist culture" (p. 185 in Chibber) by pointing out that "when migrants came to the city, they constructed new communities when they became involved in trade unions or forged new social solidarities with migrants from other parts of the country. They showed themselves capable of forming a different cultural sensibility - organized around a more secular and economic axis - than the one into which they had been socialized" (p. 196).

In the second part of the chapter, Chibber defends what he calls "a stripped-down, minimal account of rationality" (p. 199), which he defines as ultimately founded on the "the need to ward off direct bodily harm by others and the need for a livelihood" (p. 197). These two basic needs may be translated into cultural codes in any context and in turn cognized or reflected upon, but they also remain relatively exterior to any culture as basic material prerequisites for human life. According to Chibber, both the Jute Mill workers and Bengali peasants "made choices, to be sure, but what all these choices had in common was that they were in defense of their physical security. The concern for basic well-being thus constituted the grounds on which the choices were made" (p. 198). In this, Chibber asserts that "culture does not go 'all the way down' (p. 200) so as to conceal the real interest of human physical well-being.

For Chibber, political psychology is the particular form in which all that both threatens and contributes to bodily well-being makes its appearance. In contrast to Chatterjee and

\footnotetext{
${ }^{5}$ In a presentation on Chibber's book later published in Economic and Political Weekly (Sept. 14, 2013), Partha Chatterjee suggested that "political psychology" was not an appropriate category, because it had never been used by the Subaltern Studies authors, particularly Ranajit Guha.
} 
Chakrabarty who greatly emphasize the relative sovereignty, agentive capacity and dominance of such appearances among Indian subaltern classes, Chibber insists that this basic need to survive ultimately will in his words "cut through" the apparent blanket of any particular culture as if it were no more than a ghost costume. In this, Chibber decidedly is a ghostbuster.

\section{The Appearance of Labor}

There is a second manner of minding appearances that is implicit in Chibber's book and it is the understanding that particular representational patterns or mediations are specific to capitalism and, rather than as the content of a finite and discrete political psychology, are quite real and capable of shaping reality "all the way down" independent of any individual. This understanding of appearances as agentive abstractions is not directly claimed or argued by Chibber, nor is it captured by an overall term like political psychology. However, it can be gleaned from Chibber's discussion of Marx's concept of abstract labor and his critique of how Dipesh Chakrabarty has interpreted the concept.

Consistent with his overarching criticism of the Subaltern Studies project, Chibber focuses on how Chakrabarty's recent work, especially Provincializing Europe, is predicated on finding radical social difference in India that defies assumptions about capitalism based on its European history. Chibber equates what he identifies as the Subaltern Studies authors' aversion to abstract or general categories that suppress such radical difference with a particular understanding of Marx's notion of abstract labor. Chibber is correct to criticize Lowe and Lloyd (1997) for their misunderstanding of the category. ${ }^{6}$ However, in Chakrabarty's case, aversion to abstract categories in general is not the same as an aversion to the specific Marxian category, abstract labor. This can be better appreciated by considering a passage written by Chakrabarty that appeared as the second chapter in a book titled Marxism Beyond Marxism, edited by Sari Makdisi, Cesare Casarino and Rebecca Karl. Chakrabarty's essay was titled "Marx after Marxism: History, Subalternity, and Difference."

In this essay he reflected on Rethinking Working-Class History and admitted that he had misinterpreted the distinction between "real" and "abstract" labor in Marx, assuming that real labor referred to the specific efforts of an actual person:

...[M]y larger failure lay in my inability to see that if one read the "real" as socially/culturally produced... other possibilities open up; among them the one of writing "difference" back into Marx. For the "real" then, in this reading would refer to different kinds of "social" and hence to different orders of temporality.... The transition from "real" to "abstract" is thus also a question of transition/translation from many and possibly incommensurable temporalities to the homogeneous time of abstract labor, the transition from non-history to history (1995: 60).

\footnotetext{
${ }^{6}$ Chibber cites an essay that I co-authored on the relevance of Marx's value-theoretic inquiries for the anthropological study of capitalism. He includes our piece along with others who he claims make the error of interpreting "abstract" labor as referring to the empirical homogeneity of actual laboring people. However, our only reference to "homogeneous" was the same as Chibber's on page 135 in his book where he draws on the famous quote from Capital Vol. 1 on the oddity of the objectification of abstract labor that is specific to capitalism: "Let us look at the residue of the products of labor... they are merely congealed quantities of homogeneous labor..." In the Introduction to my book American Value, Migrants, Money and Meaning in El Salvador and the United States, I make the same critique of Lowe and Lloyd as Chibber.
} 
Chakrabarty continues, explaining his recognition that "the category of 'real' labor, therefore, has the capacity to refer to that which cannot be enclosed by the sign...." This gesture to Saussure's semiology and Derrida's critique of it helps explain why Chakrabarty later used the distinction between History 1 and 2 . Because he approached the capitalist commodity as a discrete Saussurian sign, a relationship between idea and utterance or structure and instantiation, Chakrabarty totally abandoned the quality of relational dynamism and interaction inherent in Marx's analysis of capitalist value determination. Chakrabarty's History 1 and 2 is as much about structuralism and its critique by Derrida as it is about Indian subaltern history. Remarkably, the anti-foundationalist critique of Sausseure's sign logic has helped provide a foundation for establishing Subaltern Studies as a widespread project of critiquing capitalism and its imperial effects from the solid foundation of a locus assumed to be exterior to it.

In his critique of Chakrabarty, Chibber argues that "abstract" is one quality or dimension of "concrete" labor and that this abstract quality is what matters, or comes to be dominant within capitalism, because of the market demands faced by capitalists. Concrete or "real" as in Chakrabarty's admission above may be understood as the wholeness of labor from which the abstract dimension or quality is accentuated and made to count in capitalism. In this sense, Chibber's critique rests on an implicit recognition that there is a dominant appearance to labor within capitalism and that this form and its maintenance is necessary for capitalism. Chibber explains that this is well understood from Marx's inquiries and as such it provides the foundation for his critique of Chakrabarty's distinction between History 1 and 2.

\section{Labor of Representation}

Chibber's argument is correct as far as it goes, but explaining abstract labor as a result of capitalists' profit drive or market logic is only part of the story. It also requires all that yields the regular sale of labor power as a commodity, its use as labor and its congealing in the tools and techniques of such labor. And most crucially, it requires the establishment of money as a universal equivalent. All this is an exceedingly complex social and historical configuration that contains a manner of representation that is necessary for its continuation. These appearances are real in the sense that they cannot be reduced to individual actors or orientations.

In Volume One of Capital, Marx poses a question about capitalism as representational proclivity by asking "why this content has assumed that particular form, that is to say why labor is expressed in value, and why the measurement of labor by its duration is expressed in the magnitude of the value of the product." The statement suggests that what is at stake in capitalism is an ensemble of representational tendencies that have become generalized, even naturalized. This is not Saussure or Derrida, but instead is the more basic recognition that capitalism entails certain systemic processes of abstraction and representation, which are continuous and unfinished processes. To grasp this means to use abstract as a verb as well as its own product, the noun form, abstraction. Determination is the aggregate social process of abstraction in that it happens independently of what any individual thinks about it. Overall, something is pulling out qualities and dimensions of something else so as to convey something else, a quality of meaning. It is the move from the possible to the actual to the general. Why does the human capacity to work upon the world take the form it does in capitalism? Why is an undefined human capacity shaped in a particular way and not others? Following this perspective, capitalism is inherently about appearances, but these do not exist in relation to their content like a dependent variable in relation to an independent one. Value as the objectification of the most abstract aspects of laborpower is the representational tendency that is specific to capitalism. Besides abstract and 
concrete, Marx also introduced private and social as two other qualities of labor under any historical conditions. Taken together they comprise all that could go into any product of human labor under any conditions, including labor power itself. This is the infinite whole from which, within capitalist relations, the abstract dimension is pulled out and represented or objectified in the commodity through its money price.

As I have intimated, it now is possible to see that the Subaltern Studies project reflected in part an academic debate over structuralism and postructuralism. Marx's approach to value determination and his understanding of representation defies both the structuralist and poststructuralist traditions. Rather than code and instantiation or infinite instantiations, it is inquiry into the historical establishment of a specific three-way representational tendency involving labor, value and labor's product and another 3-way configuration among labor-time, value and magnitude or measure. In inquiring into capitalism, Marx asked how and why these arrangements came into being and were sustained.

The current crossroads in the discussion sparked by Subaltern Studies and critiques like Chibber's is that both seem to require a foundation from which to critique capitalism. It is History 2 for Chakrabarty and it is the defense of individual interests based on ensuring human bodily well-being for Chibber. The Subaltern Studies position has been attractive over the past two decades and it joins a classic tradition in anthropology of seeking after cultures or cultural formations that provide fully formed alternatives to "western" modernity. ${ }^{7}$ (Subaltern studies scholars have explicitly remarked on the influence of British and French anthropology on their work.) An individual interest in the protection of bodily well-being may be a limit to culture or political psychology but it also is what capitalism necessarily draws upon to "universalize." It is the basis of most human medical research and the incredible translation of such science into widely consumed capitalist commodities. Protection of bodily well-being is as much the basis of capitalism as the grounds of its critique. In this, it doesn't offer a limit to any representational system nor the positive content of a horizon beyond it.

The challenge is to occupy a different kind of ground for critique that does not rely on concepts like the non-west or biology. We similarly would do well to dispense with the academic categories of economics, politics and culture-the different disciplines that substantiate their (false) separation into discrete domains, each with their own equilibriumseeking logics of supply and demand, checks and balances, and words and ideas.

If we recall Marx's early recognition that what people are anywhere and anywhen is greatly defined by what they produce - "making something more from nothing but..." and also how this is organized and accomplished, then the foundation of critique, including living struggles, is all that is not yet available or possible in the current form and organization of productive life on the planet. This is as much "cultural "or "psychological" as biological and material.

\footnotetext{
${ }^{7}$ There are at least two compelling critiques of this project written by anthropologists: Fernando Coronil's (1996)

"Beyond Occidentalism" and Michel Rolph Trioullout's (1991) The Savage Slot.
} 


\section{References}

Ascher, W. and and B. Hirschfelder-Ascher. 2003. Revitalizing Political Psychology: The Legacy of Harold D. Lasswell. Mahwah, NJ: Erlbaum.

Bhaskar, R. 1986. Scientific Realism and Human Emancipation. New York: Verso.

Coronil, F. (1996). "Beyond Occidentalism: Toward Nonimperial Geohistorical Categories." Cultural Anthropology 11(1): 51-87.

Derrida, J. 1995. Specters of Marx: The State of the Debt, the work of Mourning and the New International. New York: Routledge.

Koepping, K.P. 2005. Adolf Bastian and the Psychic Unity of Mankind: The Foundations of Anthropology in Nineteenth Century Germany (History and Theory of Anthropology /Geschichte und Theorie der Ethnologie). Berlin: LIT Verlag.

Lowe, L. and D. Lloyd, eds. 1997. The Politics of Culture in the Shadow of Capital. Durham: Duke University Press.

Makdisi, S., C. Casarino and R. Karl, eds. Marxism Beyond Marxism. 1995. New York: Routledge.

Sprinker, M., ed. 2008. Ghostly Demarcations: A Symposium on Jacques Derrida's Specters of Marx. New York: Verso.

Stocking, Jr., G. 1984. The Shaping of American Anthropology, 1883-1911: A Franz Boas Reader. New York: Basic Books.

Trouillot, M.-R. 1991. "Anthropology and the Savage Slot: The Poetics and Politics of Otherness." Pp. 17-44 in R. Fox, ed. Recapturing Anthropology: Working in the Present. Santa Fe, NM: School of American Research Press. 


\title{
CONFRONTING POSTCOLONIAL THEORY-A RESPONSE TO CRITICS
}

\author{
Vivek Chibber
}

Department of Sociology

New York University

vivek.chibber@nyu.edu

Postcolonial Theory and the Specter of Capital was written as both an intervention and a contribution to theory. It was intended to offer an assessment of one of the most influential theoretical frameworks in the humanities and social sciences since the 1990's, and a response to their criticisms of received frameworks. George Steinmetz wonders why I chose to focus so strenuously on Subaltern Studies as the stand-in for the larger theoretical corpus. He observes correctly that there are many other prominent theorists associated with Postcolonial theory (hereafter PCT), such as Gayatri Spivak, Homi Bhabha and others. The reason is that it is the historians and anthropologists in the field who have moved beyond a theory of postcolonial culture, and developed something close to a sociology of modern capitalist forms, as well as a theory of why capitalist modernization has proceeded in the way that it has. And among these more sociologically minded theorists, there is no doubt that Subaltern Studies has wielded an influence that is deeper and wider than any other current within the field. Its most prominent members have generated not only an empirically, historically based argument about the course of modern capitalism in the colonial world, but one that is remarkably coherent and consistently developed over time. As I explain in the Introduction to the book, it is not my view by any means that Subaltern Studies covers the gamut of arguments or concepts in postcolonial studies. But it is representative of many of the central ideas that are associated with PCT; it is extremely influential; and it its internal consistency makes it not just representative, but the most attractive and plausible denizen of this body of work. ${ }^{1}$

PCT claims to show that the theories and categories associated with the most influential frameworks of the twentieth century - liberal political theory and Marxist theory -- cannot apprehend the actual course of economic and political development in the colonial world. Both approaches are rejected because of their supposed determinism and teleology, which blind them to the specificity of the colonial and postcolonial world. Postcolonial theorists reject what they take to be an illicit universalism in these frameworks, a prejudice that categories and predictions coming out of the European experience must be equally relevant to the specific experience of the Global South. Because it is flawed, this universalism turns out to generate a pronounced Eurocentric bias in both liberal and Marxist theory. And this, in turn, only perpetuates the political and economic dominance of the West over the East. Or so they claim. This rejection of Eurocoentrism forms the basis of their normative critique of Western domination, and in more recent work, of the heavy hand of universalizing theories more generally.

There is a great deal at stake here. If the arguments coming from Subaltern Studies are correct, then we are obligated to overhaul much of what is currently practiced in the social sciences and humanities, roll up our sleeves, and craft entirely new frameworks for understanding the evolution of much of the world. Even more, the foundational basis of our criticism of modern capitalism has to be rejected and new political theories have to be crafted

\footnotetext{
${ }^{1}$ I offer a more elaborate explanation for my decision to focus on Subaltern Studies in "Making sense of postcolonial theory - a response to Gayatri Spivak," Cambridge Review of International Affairs, Fall 2014, which I do not want to repeat here.
} 
that have no truck with Enlightenment universals. It is therefore a little surprising to see how little effort there has been toward a serious assessment of the actual evidence that PCT adduces in support of its claims about the actual differences between East and West, the shortcomings of the received frameworks, the real drivers of historical trajectories, the fount of social agency, etc. So the first challenge I undertook in Postcolonial Theory and the Specter of Capital (hereafter PTSC) was to assess these arguments on their own grounds. And by this I mean, to reconstruct them, to tease out their implications, and then to see if they stood up to empirical and logical scrutiny.

My verdict in the book is that the arguments developed by PCT and Subaltern Studies fail on both theoretical and normative grounds. With regard to theory, PCT fails in its Subalternist version because it cannot adequately explain the patterns of historical development in the advanced and late developing parts of the capitalist world. It insists that the defining characteristic of the Global South is its deep and abiding structural differentiation from the advanced capitalist world, a difference so deep, so fundamental that it requires an entirely different set of categories. I examine these claims and argue that none of the arguments adduced in their favor withstand scrutiny. There are differences between the two parts of the world, of course; but they are not of a kind that resists analysis through the inherited explanatory frameworks. I conclude that the Subaltern critique of Enlightenment theories is baseless. Furthermore, I argue that the arguments made by Subalternists for the specificity of the East are not only questionable on empirical grounds, but that they also cannot provide the basis for political critique. This is because, their rhetoric notwithstanding, they end up reviving and refurbishing some of the most objectionable Orientalist canards about the East. So, far from providing a means of overturning Eurocentrism, Subaltern Studies gives it a new lease on life for Eurocentrism is just the dual of Orientalism.

\section{The Universalization of Capital}

Well, these are my conclusions. What are the bases on which I defend them? We start with an assessment of the Subalternist argument against the universalizing categories of Enlightenment thought, chief among which are the ones central to Marxist and liberal social theory - categories like capitalism, universal rights, class, citizenship, etc. PCT and theorists from Subaltern Studies argue that the relevance of these categories is highly dubious outside the West. The reason for this is that they presume that the social milieu that they are examining has been transformed in some relevant way by capitalism - in other words, their use presupposes a properly universalizing capitalism. But - and this is the key - capitalism failed to universalize once it left European shores. It is not that the transformation that it is supposed to bring about is yet incomplete. It is, rather, that capital mutates in such a way that it cannot universalize. Dipesh Chakrabarty is especially emphatic on this point. Subalternists deny that it is just a matter of waiting until the social transformations associated with capitalism are complete. Their view is that capitalism cannot universalize, and this is why the categories of the Enlightenment are irredeemably flawed when they are put to use in the East.

So what accounts for the necessity of capital's failed universalization? There are two arguments that Subalternists make in this regard, one developed by Ranajit Guha and the other by Dipesh Chakrabarty. For Guha, the key lies in a deep historical failing in the colonial and postcolonial bourgeoisie, namely, that it failed in its duty to "speak for all the nation", to create a liberal political culture in which political rule was based on the consent of the masses. He contrasts this with the experience of the West, in which capital created a culture of rights and 
liberality, in which rulers treated the ruled as formal equals even while they exploited them. The pivotal events in which capital advanced this agenda were the great bourgeois revolutions of 1640 in England and 1789 in France. But in India, in its "bourgeois revolution", i.e. the Independence movement, Indian capital forswore any such mission. Instead of overthrowing the ancient regime, it accommodated to it and instead of embracing its mission to speak for all the nation, it chose only a pursuit of its narrow economic interests. Hence, capital's rule in the East turned out to be based on outright domination rather than on hegemony, whereas in the West, the poles were reversed - capital ruled hegemonically, and coercion played a subordinate role. The different character of the bourgeoisie in the two instances created radically different political maternities.

Dipsesh Chakrabarty accepts Guha's historical sociology, but adds to it another dimension, which provided independent grounds for the denial of capital's universalization. He begins with the observation that capital strives to subordinate all social relations to its own logic. But, he says, this compulsion is not equally successful across the board. There are some practices that do become absorbed by capital. Chakrabarty calls these practices "History1." But then there are others that, even while they are influenced by capital, still manage to retain their integrity and resist total subordination. These Chakrabarty calls "History2." Chakrabarty then adds the proviso that for capital to have successfully universalized, it must be the case that History1 obliterates History2. But of course, he observes, History2 can never be extinguished. No social formation loses all traces of its local culture, local institutions, etc. He then concludes that, since History 2 can never be extinguished, since some social practices resist the "totalizing" drive of capital, we must acknowledge that capital never in fact succeeds in its universalizing drive. And since it does not successfully universalize, the universalizing categories of the Enlightenment, which presume that Historyl has in fact won out, only serve to obscure the real nature of post-colonial societies. They fail to appreciate its heterogeneity, they wipe all traces of social differences, and impose on this rich diversity the homogenizing categories of Western thought.

In assessing these arguments in PTSC, I take a conservative approach. I grant to the Subalternists their premise - which is by no means obviously correct - that for Enlightenment categories to have relevance, capital must be shown to retain its universalizing drive. As it happens, I believe that the premise can be easily rejected, but I keep to it in order to make the Subalternist case as strong as possible. So let us assume that it has warrant. Can we agree with the claim that capital cannot universalize once it leaves Western shores? I argue that neither argument for capital's abandonment of its universalizing drive can be defended.

Guha's argument for there being a historic break between the political projects of the bourgeoisie in the West and in the East flows from a highly mythologized story about the great Bourgeois revolutions, one that was rejected decades ago by historians. I show this in great detail in Chapters Three and Four in PTSC. All the critics in this forum accept both my reconstruction of Guha as well as my criticism of him. But William Sewell worries that while my basic argument regarding the so-called bourgeois revolutions is convincing, I am not sufficiently attentive to some of the real shifts that they did facilitate, and he brings up, as an example, the importance of 1688 for the separation of powers in the English state and that of 1789 for ideas such as the Rights of Man. But Sewell is reading my argument in an unduly narrow fashion. My argument for the importance of the English and French revolutions is meant to assess whether they performed the functions assigned to them by Guha, and for him, their achievement is very specific - they were instances in which capital fought for, and successfully created a political 
culture based on the inclusion of the laboring classes, in which their participation in the political process was not only allowed but welcomed by the new ruling class. My downgrading of the revolutions achievements should be read against the claims that I am assessing. I do not deny their significance altogether. It is not that I am unaware of the shift toward a constitutional monarchy in England or the promulgation of the Rights of Man in France. My argument is twofold - that the shifts that did occur were nowhere near what is needed to validate Guha's argument, and second, that in so far as there was a movement toward greater inclusiveness, it was not because of the universalizing mission of capital, but because of pressure from the laboring classes. Sewell is correct in his claim about the Revolution's legacy for the issues he raises, but his observation is quite consistent with my argument.

I am pleased to see that all of the critics also largely agree with my rejection of Chakrabarty's argument, though they raise some related issues that are quite interesting. Chakrabarty sets up a test for the universalizing process that is absurdly stringent, one that, to my knowledge, no social theorist has ever countenanced. I argue against Chakrabarty that capital's universalization does not at all require that capital absorb History 2 into its logic. For that to be the test, it would require that every social practice, every aspect of culture, ideology and social institutions become reflections of capitalist imperatives. The mind boggles at the thought. A more reasonable litmus is that capital merely has to ensure the subordination of economic practices to its logic, moving against the autonomy of cultural and social practices only if they interfere with or undermine the economic. Chakrabarty only allows two possibilities in his universe - practices either directly support capitalism or they are a threat to it. But it is entirely possible that practices can be outside the orbit of commodity production and be neutral toward it - a possibility that he does not consider. But if this is so, then there is no necessary conflict between History1 and History2, and the non-incorporation of History2 is not evidence at capital's failure to implant itself. Furthermore, Chakrabarty is mistaken in locating the sources of instability to capitalism in History2. I argue that the most important sources of instability are in fact exemplars of History1 - centrally, problems within the accumulation process itself, which lead to economic breakdown, and laborers' defense of their material interests, which are universal in scope.

George Steinmetz raises a very pertinent issue when he wonders if my arguments for History1 as the main source of instability are too hasty in pushing aside the importance of History2. He observes, correctly, that I put a great deal of weight on may claim that capitalism can subsist in happy coexistence with practices and institutions in History 2 , and hence, that an affirmation of its universalizing drive need not blind us to the fact of historical diversity. But, Steinmetz suggests, is it not possible that there might be plenty of instances in which elements of local cultures or practices, in places where capitalism is taking root, might in fact be inimical to its reproduction? If so, should we not take seriously the corrosive powers of History 2 for the universalizing tendency of capitalism? I entirely agree with Steinmetz on this, and in fact, I point out in PTSC that History 2 can block or destabilize capitalist reproduction (pp. 228-229). My argument is not that History 2 can never be a source of disruption; it is that whether or not it is so is a highly contingent matter, whereas there are elements of Historyl that are systematically in tension with the stability of capitalism. I argue for the asymmetry between the two as sources of instability within capitalism, not for the irrelevance of History2 (p. 229).

Steinmetz also proposes, in a related argument, that I could have tried for a more ramified conception of political forms, presumably in Chapter Five where I discuss the kinds of power relations that are consistent with capitalism. He regrets that I confine my discussion to the labor 
process, to the detriment of any consideration of the state or other political institutions. If I had done so, he continues, I might have considered how there have been instances in which colonial states blocked the spread of capitalist relations - not liberalism, but the production relations of capitalism itself. This would be an instance of the actual blockage of the universalizing tendency, even on my definition of the term. Steinmetz is again quite right. In the history of colonialism, there have in fact been plenty of instances in which states impeded the growth of capitalism by giving support to traditional social relations. But my ambition was not to insist that capitalism has taken root in every corner of the globe, or to present colonialism as an engine for capitalism's growth, as Bill Warren (1980) did famously in his work a generation ago. As I say in PTSC, whether or not capitalism has in fact taken root in a colonial setting is an empirical matter (see pp. 125 fn.39, 144-45, 145 fn. 31); it did so unevenly, sometimes very slowly, sometimes rapidly, and sometimes it was not until the postcolonial era that it spread. There are even regions where its development continues to be episodic and weak. My argument was that even where such developments occur, they cannot provide support for the Subalternist argument, which are not that capital's universalization might be blocked here and there, but that it either loses its very capacity for universalization (Guha) or never had it in the first place (Chakrabarty), since it is necessarily blocked by History2. To put it more precisely, Steinmetz suggests the possibility of a causal property's realization being blocked, while the Subalternists argue for that property being shed altogether. PTSC is ranged against the latter argument, and happily acknowledges the possibility of the former.

\section{The Other Universalism}

So, one kind of universalizing process that is defended in PTSC is the spread of capitalism around the globe. A second one that occupies a prominent place in the book is the fact of some universal basic needs among human beings, and from that I derive the possibility of real interests that bind together members of a class. In PTSC, I show that Partha Chatterjee and Dipesh Chakrabarty deny both the motivational force of basic needs, as well as the salience of individual interests for non-Western actors. They do not reject the very idea of real need and interests - they just think that Eastern minds are not motivated by them. I show both that their arguments against the salience of interests are mistaken, and indeed, that the empirical research of Subalternist historians - including and especially Chatterjee and Chakrabarty - itself demonstrates that nonWestern actors are every bit as aware of their objective interests as are western ones. All of the critics seem basically sympathetic to my argument, though Steinmetz and Sewell both express some skepticism toward my positive account of practical reason, Sewell worrying that it amounts to a version of rational choice theory, and Steinmetz seems to think that my view amounts to a denial, or at least a denigration, of the fact that all action is meaning-oriented.

Does my argument amount to a version of rational choice theory? I proposed in PTSC that it does not, in large measure because I reject a maximizing model of rationality. But perhaps Sewell is right that this does not merit casting it out of the family of rational choice. In the end, the label matters less than the plausibility of the core arguments. Steinmetz's concerns are more germane here, since they question the viability of my arguments. But he is mistaken if he thinks that my view calls for meaning-free action. The affirmation of rationality does not require that social agents perform their actions outside the meaning universe that they occupy. I go to some lengths in PTSC to make this clear (pp. 183-200, esp. 193-196). What it rejects is the idea that the acculturation of social actors can be such as to make them oblivious of their basic needs; I suggest that the pursuit of these needs does not exist outside of culture, but that, because they act 
as such a powerful motivational force, cultures have to create codes and conventions that respect and acknowledge them. I cannot develop this point here, for lack of space, but I refer readers to the discussion in PTSC, Chapter 8, Sections 3 and 4. My point here is that Steinmetz seems to have misunderstood my argument, and imputed to me a view that I explicitly reject. Now, it could be that I am mistaken in believing that it is possible to uphold the reality of interests, while also allowing that all action is meaningful in orientation. So perhaps it is the case that arguing for basic needs and objective interests requires that we take actors to be asocial or outside of culture. But I do not believe that this is so, and in my view, sociological theory, as it is practiced today, is burdened by a quite profound confusion around this issue.

The needs that I affirm in PTSC play a central role in any viable social theory. As Doug Pederson correctly observes, it is on their basis that we can explain the ubiquity of resistance to social domination - especially resistance to wage labor; but, Pederson continues, even the very spread of capitalism is hard to explain except by reference to actors' real needs. It is hard to see why laborers in every part of the world, every culture, in every setting where they are expropriated, end up offering their labor power for sale, if it is not because of their desire to uphold their physical wellbeing. And it is equally hard to see why the wage contract breeds resistance and conflict in every part of the world, if it is not because those same laborers try to defend their autonomy and their well-being against the depredations of their employers.

Now Michael Schwartz is certainly correct in his observation that while I stress the importance of universal needs and interests, it remains insufficiently developed in the book. The main problem is that while I maintain their ubiquity as sources of motivation, I do not give much of an explanation for why their actuation or efficacy is so uneven. My failure on this score is partly because of space limits - there is only so much a book can do. But it is also for two other reasons. The first is that, as a work of critique, the book will tend to operate on the same level of generality as the theories that it interrogates. Since the basic Subalternist argument is for a denial of individual interests, I naturally strive to demonstrate their salience as a basic social fact. I pay less attention to the variations in their realization. But the second reason is that there is a veritable ocean of social science research that does just this, and Schwartz's scholarship is a great example of some of the best work that assumes rationality on the part of actors and then explains the variations that he points to. My goal in the book was to suggest that this enormous body of work is not vulnerable to the criticisms that PCT makes of it - that it gives short shrift to culture and to agency, that it is parochial, that it denigrates social differences, that it homogenizes the social landscape, etc. And having shown that these criticisms are unfounded, PTSC suggested that we can go back to this work to continue the project of understanding the real sources of social contestation, since PTC does not offer much in this direction.

\section{Conclusion}

So what PTSC argues, in the end, is that Subaltern Studies fails in the case that it makes against the universalizing categories of the Enlightenment, which includes liberal and Marxist theory. This is important, because as I suggest early on in this essay, the Subalternists have made the best and most careful of all the arguments in the postcolonial arsenal. It is important to note what the implications are. Bruce Cumings objects to my characterization of their arguments, in particular to those of Chakrabarty, as Orientalist. He wonders what is wrong with Chakrabarty's ambition to generate a framework that is "attuned to Indian realities and freed of European assumptions." But my criticism is not directed toward Chakrabarty's ambition, since it is one that I entirely endorse. What makes Chakrabarty's arguments Orientalist is not their stated goal, 
but their content. Insisting that non-Western people do not have a bounded conception of the self, that they are only motivated by obligations to larger groups, that their consciousness is fundamentally religious, while Westerners are basically secular, that the reliance on Reason is a Western convention, that rationality and objectivity are Western - these are the claims that Chakrabarty and his colleagues make, and it is on the basis of these ideas that I characterize them as Orientalist.

It is gratifying to see the response that PTSC has generated in so short a span, even though much of it has been hysterical, as I predicted in my concluding chapter. The reason is not hard to fathom - as Ho-fung Hung points out in his introduction, there is a great deal at stake in this debate, not just intellectually, but also politically. PCT has emerged and flourished at a time of general retreat for progressive forces, perhaps more so than any other time in the modern era. For the generation of students and activists just coming of age, the only form of critical or radical theory they have ever encountered is some version of PCT or its cousins. Many of the ideas associated with progressive movements of the past century - of universal emancipation, egalitarianism, class organizing, internationalism - now seem quaint to them, if not odious. These are the ideas I try to defend and revive in PTSC. Perhaps Michael Schwartz is right that, in the not too distant future, the theories associated with PCT will seem as little more than a bizarre interlude, a temporary descent into self-absorbed tomfoolery by intellectuals. But here today, it is apparent that these currents, however odious their ideas may be, wield tremendous influence in the intellectual landscape. One can only hope that Schwartz is right and that it will soon be behind us.

\section{Reference}

Warren, B. 1980. Imperialism: Pioneer of Capitalism. London: Verso. 


\section{Book Reviews}

\section{Ben Selwyn. The Global Development Crisis. 2014. Malden, MA: Polity. 224 pages, ISBN 978-0745660158 Paper (\$24.95).}

In his 1930 essay "Economic Possibilities for our Grandchildren," Lord Keynes declared, "for at least another hundred years we must pretend to ourselves and to everyone that fair is foul and foul is fair; for foul is useful and fair is not." Only then could the gods of "avarice and usury ... lead us out of the tunnel of economic necessity into the daylight." Sacrificing the present for the future was at the heart of the social democratic compact. Workloads would be reduced from shared productivity gains. Capitalists' animal spirits would be deftly managed by government lion-tamers. Fishing in the afternoon and reading Plato in the evening seemed to loom on the horizon for working classes, as long as they were patient and prudent in their demands.

In his 1952 collection Ten Great Economists, Joseph Schumpeter was unimpressed by Keynes' theoretical cutlery: "A fruit knife is an excellent instrument for peeling a pear. He who uses it in order to attack a steak has only himself to blame for unsatisfactory results." Keynes hadn't written a general theory at all, Schumpeter observed, just a theory of the British economy. Actually existing capitalism did not remain within the lines airily drawn by methodological nationalism. As Perry Anderson pointed out, "The idea of capitalism in one country, taken literally, is only a bit more plausible than that of socialism [in one country]." Grandchildren of Keynes' generation watched the global reach of capitalism shred, not fulfill, the social democratic compact.

Like Schumpeter's collection, Ben Selwyn's The Global Development Crisis focuses on a set of pioneering economists and social thinkers in order to put forth a series of theoretical propositions about the world economy. Compiling and updating recently published articles, the welcome result is a Marxian analysis of historical capitalism more syncretic than dogmatic. Selwyn is an insightful and prolific scholar. He is not looking for the pear peeler but for the steak knife. Where does he find it?

Selwyn begins by mapping out the unequal structures of the world economy. He highlights the inherent conflicts within processes of capital accumulation and class formation. The book relies on the concept of exploitation as the "pre-condition and basis of the capital-labor relation," operating through the extraction of surplus value through waged labor (p. 5). Selwyn argues capitalist exploitation takes place in multiple social arenas: the workplace, labor market, household, cultural/racial formations, and nature. This seems like conceptual stretching, and makes for a bit of trouble later on; Selwyn admits he mostly pays attention to the first two areas in the book (p. 15). Yet the underlying point is to show the weakness of "residualist" theories which assume solutions to global poverty and underdevelopment can be sought in more economic growth and market inclusion. "Relational" theories investigate how relative and absolute poverty are produced in conjunction with capital accumulation and wealth. To shape his analysis, Selwyn turns to thinkers outside of the straitjacketed neoclassical tradition which Albert Hirschman once labeled "monoeconomics": List, Marx, Gerschenkron, Trotsky, Schumpeter, Polanyi, and Sen.

Friedrich List, based on his experiences in the early $18^{\text {th }}$ century United States, theorized the "infant industry" approach to state-led development. The laissez-faire cosmopolitanism espoused by British political economy did not ensure catching up to the imperial hegemon but rather guaranteed peripheral impoverishment by kicking away the development ladder. States 
needed to shelter nascent manufacturing, promote educational-technical cadres, and collate together a national market economy through infrastructural projects. List is thus the father of what Selwyn calls the "Statist Political Economy" approach to development studies: here we find Alice Amsden, Robert Wade, Ha-Joon Chang, Atul Kohli, and Peter Evans. This school was the loudest critic of neoliberal proclamations that a country could simply trade its way out of poverty. Drawing from Marx's own writings on List, however, Selwyn teases out two contradictions in the Statist school. Where successful, state-led development relied on heightened repression and exploitation of local workers. Indeed, in his 466-page tome, Kohli (2004) essentially admits that fascism is the best way of fostering industrialization in poorer countries (he relegates the starkness of the comparison to footnotes). Selwyn also points out that List's unabashed advice for German state-builders was protection at home and military imperialism abroad. These were structurally linked in practice. Thus contemporary state theorists whitewash both the historical record and the theoretical implications of List's thought. They may hope for a social democratic model, but their own cases show that state-led development, from Stalinist industrialization to East Asian tigers, regards workers as no more than "fuel for the accumulation of capital" (p. 51).

Marx would be a logical source for moving beyond such contradictions, but which Marx? Largely devoid of tiresome Marxology, Selwyn continues in the tradition of Andre Gunder Frank and Giovanni Arrighi by reconstructing Marx as theorist of a global, uneven, contingent, and historically non-linear capitalist system. It is time to take down the barricades from such nondebates as Robert Brenner vs. Immanuel Wallerstein, Selwyn shows, and instead synthesize the 1970s transition debates into a useful theoretical apparatus. Selwyn also constructs a handy typology on the developmental impact of class struggle from Marx's writings: workers in colonial frontier zones escaping the reach of states and capitalists (the Australian hinterlands); communal peasant organizations resisting the penetration of capitalism (the Russian mir); emergent workers' structural and associational bargaining power forcing the improvement of livelihoods under capitalism (English trade unionism); and the creation of political-economic institutions which undermine capitalism (the 1871 Paris Commune). This is the kernel of a "labor-centered perspective," which Selwyn argues should replace our current development theories.

Leon Trotsky and Alexander Gerschenkron take us a step further. They both show how state attempts to catch-up in the world economy reshape domestic class relations, which, in turn, can effect and even undercut state efforts. Gerschenkron went beyond List by identifying why particular advantages of backwardness for poorer countries are not replicable over multiple iterations. New institutional innovations, which cannot be predicted beforehand, create the pathways for each generation of late developers. This is the theoretical insight from Gerschenkron's analysis of German banking vs. Russian statism: each successful case of catchup development forces changes in the global political economy, resulting in "continual divergence from earlier cases of industrialization" (p. 85). The process makes the Statist school's advice to repeat late developer examples of the past, Selwyn suggests, mostly irrelevant for policy in poorer countries. Gerschenkron partly developed his thought by reading Trotsky, whose notion of "uneven and combined development" has been resurrected by International Relations scholars such as Justin Rosenberg. Peripheral countries like Russia benefitted from the advantages of backwardness, Trotsky claimed. Yet by rapidly integrating into world economic relations under the "whip of external necessity," the result was not a mirror of earlier developmental paths. Rather, a combination of new and old forms of social organization ensued. This would likely produce new forms of social conflict as well. High levels of capitalist 
exploitation and state repression in late developers made for more explosive cross-class mobilization in response from below. Changes in global political economy after rounds of successful late development also meant that the disadvantages of backwardness would multiply. Unmentioned by Selwyn, this is Peter Evans' well-known argument in Embedded Autonomy: that state-led development produces its own gravediggers via "the social constituencies that it helps bring into being" (1995: 229). (Given that Evans evokes Marx to make his point, Selwyn is perhaps a bit uncharitable towards the Statist school.)

Selwyn then weaves together Joseph Schumpeter and Marx in a commodity chain perspective of global economic dynamics. Innovations by leading economic sectors not only result from firm-level competition and entrepreneurial search for super-profits, but also from labor struggles along the production nodes of commodity chains. Technological changes and their resultant rents are spatially clustered within wealthy countries. Organizations such as the WTO buttress the borders of an "upgrading club" to which only Northern states can belong. Meanwhile, the spatial disaggregation of production allows transnational corporations to subcontract out high levels of labor exploitation to poorer states. Selwyn is firmly in worldsystems territory here, summarizing work by Arrighi, Beverly Silver, and Denis O'Hearn. To tease out Selwyn's point further, one can characterize his argument as such: capitalist creative destruction does not produce an irrevocable race to the bottom or convergence towards a flat world, but rather a global process of uneven and combined development which generates social conflict in new and unexpected locations.

Two chapters devoted to Karl Polanyi and Amartya Sen are impressive but less satisfying. They repeat well-known assessments of these authors' work. Polanyi's conception of an organic double movement against commodification and market society ignores the power dynamics of capitalist social relations. Sen's call for human development along multiple axes beyond economic growth is laudable, yet his benign view of market inclusion is more "residualist" than "relational." Selwyn's critique of both: it's the exploitation, stupid!

Here lies the problem. In placing various mechanisms of domination and exclusion into the conceptual kitchen sink of exploitation, Selwyn is a bit of a residualist himself. Theorists such as Arrighi (also drawing from Marx) identified relational yet separate processes of exploitation and exclusion as mutually constitutive mechanisms of global capitalist dynamics. We cannot explain the one without the other. To lump it all together under a bridging concept of exploitation may be satisfying for critics of capitalism, but it also can be analytically confusing and politically frustrating. Yet by noting how labor struggle is a constitutive element of historical capitalism, Selwyn is pushing in the right direction. His theoretical cutlery is far sharper than the current wave of left-leaning handwringing which sees a blob-like neoliberalism behind every form of social change. By taking these essays into consideration, perhaps our grandchildren will not, to paraphrase Keynes, become enslaved by some defunct economists. 


\section{References}

Evans, P. 1995. Embedded Autonomy: States and Industrial Transformation. Princeton, NJ: Princeton University Press.

Kohli, A. 2004. State-Directed Development: Political Power and Industrialization in the Global Periphery. Cambridge: Cambridge University Press.

Kevan Harris

Department of Sociology and Mossavar-Rahmani Center for Iran and Persian Gulf

Studies, Princeton University

kevanh@princeton.edu

Nicole Constable. Born Out of Place: Migrant Mothers and the Politics of International Labor. 2014. Berkeley, CA: University of California Press. 259 pages, ISBN 9780520282025 Paper (\$29.95)

In Born Out Of Place, Nicole Constable sets out to write about "babies born of migrant worker mothers abroad" (p. xii) and the experiences of migrant mothers living and working in Hong Kong. The contradictions are numerous for these families: temporary migrant workers suddenly tied to a foreign country, domestic workers disciplined privately by their employers and again publicly for their sexuality, currents of opinion from their home societies and the families left behind which at once celebrate migrant women's contributions yet chastise their babies born abroad. These paradoxical narratives make for a captivating read, as Constable pairs her analysis with rich ethnographic evidence that delves deeply into the intimate and difficult details of the lives of children "born out of place" to their migrant mothers. The book is a fascinating exploration into migrant motherhood from a vantage point that has yet to be studied and theorized - that is, the experience of migrant women who have children during their migratory experience.

Constable situates the experience of migrant domestic workers in Hong Kong who have children while working and living abroad in the problems of contemporary neoliberal migration schemes. She opens her study with a critical analysis of the policies, institutions and cultural logics that have profited from feminized migrant labor, both in the Global North and the Global South. In her succinct and valuable preface, Constable delineates the three main arguments she aims to tackle in her book. The first is that migrant workers are rarely seen as anything but laboring bodies whose services are available for the consumption of their employers. They are shipped out from home countries and received by host ones who accept them as workers only. This restricted conception of migrant women workers makes the possibility of interpreting their lives in a holistic and humanized way impossible. Therefore when migrant women workers have babies or relationships, they are deemed failed workers or immoral women.

Gender is a central analytic in producing the tension between "good migrants" and "good mothers" as it shapes the stigmatized idea of single migrant motherhood. In chapters four and five, Constable writes in-depth profiles of the women and men, the parents of the babies born in Hong Kong, showing how gendered ideas about marriage and motherhood ultimately conflict with the reality of migrant parents' lives. In chapters six and seven, Constable explores the legal advantages and disadvantages of migrant mothers whose babies are born in Hong Kong. She 
discusses the lived experiences of these women and their children on a continuum she calls the "Migratory Status of Mothers," whereby they experience more or less privileged or precarious statuses which shape their chances to work, stay, or claim legal status for their children. For migrant women who are legally married or have legal work status, Constable argues that patriarchal constraints of "good" motherhood and womanhood nevertheless circumscribe the lives of these relatively "privileged" women. On the other hand, migrant women who occupy precarious positions on the spectrum have few options, such as seeking asylum or filing torture claims and overstaying, that often put them in vulnerable positions legally. Yet the gendered policies cannot keep migrant women from staying in Hong Kong, as it is often the best decision for their babies in terms of generating income, combatting stigma, or staying together as a family. The ability to be a good migrant worker and a good mother is in opposition, thereby supporting Constable's first argument that women workers are only seen as workers, no more, no less.

The book's second intervention argues that the efficacy of temporary immigration policies that are supposed to monitor and regulate the provisional stays of migrant women workers in Hong Kong have an opposite effect. In fact, migrant mothers often overstay or use legal avenues to stay in Hong Kong precisely because they are pregnant or have children, thus clashing with the policies' original intentions. A strong substantiation of her second argument is Constable's framing of migrant women workers and their children's lives as articulated through juridical modes. The contradiction in juridical terms here is quite interesting, as the law that is supposed to control and discipline the migrant population also provides migrants the opportunity to circumvent it. In chapter three, Constable describes the legal disciplinary measures, both in Hong Kong and migrant women's home states of Indonesia and the Philippines, which make it impossible for migrant women to fulfill their duties as domestic workers when they give birth to their babies abroad. Hong Kong laws, such as the "two-week rule" that requires migrant domestic workers to depart fourteen days after termination or the process of filing a labor claim, disqualify women to work legally during times of unemployment, leaving them unable to support their new babies and families at home. Building on her first argument, she shows how the narrow conception of migrant women as strictly workers, and the failure to take into consideration their identities as mothers, merge with the juridical treatment of migrants via immigration policies and legal institutions that then push many women to overstay and work illegally.

The third major argument that Constable makes takes on a transnational examination of the stigma and pressures that migrant women face from family members in their homelands. In what she calls, the "migratory cycle of atonement," Constable argues that serial migration becomes the only recourse for migrant women because of the shame and stress they face from their families upon return with their babies. Migration and remittances become the saving grace for many single migrant mothers. Constable introduces the concept of "cruel optimism" in the first chapter, borrowing from Lauren Berlant (2011), to discuss the potential and promise of child-rearing in the context of such steep inequality for migrant women. "Cruel optimism" is a helpful concept, as it encapsulates both the hopeful potential migrant women experience as they welcome their babies to the world, and also the difficult context under which migrant women workers make decisions that are often detrimental for them and their children. Chapter eight probes more into the paradox of gender and provides a convincing explanation of why migrant women often choose the solution of cyclical migration to atone for their babies born abroad.

Constable is successful in using these three arguments to demonstrate the chronic problems with temporary migration and the affixed issues of citizenship and belonging. With great care, she blends the theoretical contributions and lived details of migrant mothers and their 
babies "born out of place," arguing that gendered labor demands and the neoliberal response visà-vis temporary immigration policies promote a dehumanized and limited perspective on migrant workers, the value of their work, their lives, and the lives they bring into this world. Constable introduces these three arguments early, thereby allowing readers to quickly identify that neoliberal immigration policies are flawed. She then goes on, in the face of that critique, to offer an important portrait of migrant workers as whole people, humanized and multi-faceted, caring and fickle.

Another strength of the book is in the second chapter where Constable describes two trends in the research on migrant domestic workers as either a view from above-an analysis of macro, structural constraints on migration and labor-or a view from below-work on micro interactions and thick descriptions of how migrant women make meanings of their lives. She positions herself somewhere in the middle of these currents. As the book progresses, Constable writes a fair analysis of laws and policies as well as providing lengthy stories of the participants in her study, thus giving the reader a glimpse into how individuals negotiate and work within structures. In this chapter, Constable reports on her knotty positionality as a researcher that is not a "detached observer." Through her participant observation and immersion in her participants" lives, she describes the complicated ways her research process was intertwined in the even more complicated lives and needs of migrant mothers and their babies. It is refreshing to see a scholar take seriously how ethnography can be a way to understand the banal but also admit that it is challenging and problematic. The methodology piece of the book honestly reveals that the dynamics of research are often extractive, even if researchers are always trying to figure out how to "give back." Overall, Constable is successful in fulfilling her stated objective to contribute to the literature through using a middle ground approach in analyzing the juridical modes that define the lives of migrant mothers and their babies. Moreover, she also admirably expresses the hope that her work can contribute to a social justice struggle to make these families' lives visible.

Some issues that remain are the absence of the discussion of children that were born to their mothers before migration and the status of their transnational relationships to them. Additionally, there were many stories of violence in the ethnographic examples of migrant mothers, and giving context about the patriarchal logics of migrant masculinity in what R.W. Connell calls the "world gender order" could have been beneficial to situate how migrant femininity and masculinity are produced together. In the main, Constable's book will be useful for those who are interested in exploring the literature on global sociology, immigration, gender, domestic workers, and ethnography.

\section{References}

Berlant, Lauren. 2011. Cruel Optimism. Durham, NC: Duke University Press.

Valerie Francisco, Ph.D.

Department of Sociology and Social Work, University of Portland

Francisco@up.edu 
Cynthia Enloe. Seriously! Investigating Crashes and Crises as if Women Mattered. 2013. Berkeley, CA: University of California Press. 248 pages, ISBN 978-0520275379 Paper (\$29.95).

Most academics and activists who focus on questions of gender are well aware of the adverse effects of particular development policies or programs on women, most of which assume that women are victims whose interests and needs are peripheral to policy planning or implementation. When women are included, it is generally only in programs designed and implemented for their direct participation. A number of critical feminist analyses of policy processes, however, recognize that women are integral to all social, economic, and political practices, whether they are direct beneficiaries or not, and challenge the presumption of genderneutral policies and interventions. Among this latter group, Cynthia Enloe, in Bananas, Beaches, and Bases: Making Sense of International Politics (first published in 1989 and reissued in 2000), was among an early group of scholars who challenged the notion of gender neutrality and argued, instead, that women are constitutive of all social processes. As a prolific writer whose contributions have been central to discussions across the social sciences for more than twentyfive years, Enloe recognizes that despite years of struggle, women's interests and concerns continue to be excluded in policy planning and in aid and development program implementation. Offering a political economy of gender, her recent contribution, Seriously! Investigating Crashes and Crises as if Women Mattered, confirms the need to treat women's, interests, place, and experiences seriously. This most recent contribution leads one to ask what has transpired in the intervening 25 years since she first raised this issue that requires reconfirmation of what, by many accounts, should by this time, be obvious to activists and academics alike. What does Seriously! offer as a counterpoint to those for whom women continue to be an afterthought in policy and program implementation and in analyses of crises that characterize the current conjuncture?

To respond to the question of why there is a need to reconfirm the importance of gender difference and patterns of women's exclusion, it is necessarily to reflect on the consequences of the sustained attack on women's rights in the U.S. and on what this regressive turn might mean for current undergraduates who are an important audience for Seriously!. I am especially attentive to this constituency since, as director of a feminist, gender, and sexualities studies program, I have been directly engaged with students who have varied responses to the study of gender or feminism. It is immediately clear, for instance, that some students take for granted the hard fought struggles of an earlier generation to gain reproductive choice or challenge institutional discrimination. Others presume, without much historical reflection, that understanding gender relations, or the differential effects of policy or program reforms on women and men, is neither a relevant nor significant concern. For these students, Enloe's persistent refrain - we must take women seriously-acknowledges and addresses these presumptions and the ongoing need for their repetition and elaboration. The important contribution of Seriously! is to offer the current generation of students suggestive examples for how and why women matter in analyses and interpretations of various policy and program interventions and the significance of movements from below in demanding such recognition.

Seriously! is divided into nine chapters that highlight Enloe's creativity as a feminist political scientist of international relations. The narrative is methodologically innovative, engaging a comparative historical lens that draws on her early experience in Malaysia. She opens with personal reflections on her early career decision not to focus on women and what this 
experience, and being a young and lone woman faculty member in a political science department, has meant for her scholarship and activism. For students and activist neophytes, these experiences emphasize the criticality of historically grounded personal biography in understanding processes of social change and the role of campus and community activism in its realization. Two case studies animate the text, one, the Dominique Strauss-Khan (DSK) Affair and the banking crash of 2008, and a second, the contemporary recession. Through these accounts, Enloe brings to bear an understanding of contemporary crashes and crises that have usually been examined as if gender didn't matter - where the term "men" refers to people, not men, and women are nowhere in sight, except when they are the specific focus of research or victims of these happenings.

Examining the "DSK" affair and the financial crisis in Europe and the U.S., Enloe skillfully employs case studies and debate to highlight macro-level processes and relations. In the DSK affair, for example, she showcases what we can learn when recognizing that people, but importantly organizations, too, produce cultural valuations that shape and valorize acceptable behavior and legitimate particular policy formulations. Workplace culture is thus important for understanding the relations of production in organizational settings and the shift from prizing thrift and solidarity, reminiscent of a bygone era, to the "shameless indulgence in luxurious consumption out of the reach of most of their fellow citizens" (p. 79). As importantly, Enloe reveals how in order to fulfill the IMF's loan requirements, national governments seek to maximize local citizens' unpaid and low-paid labor, reduce the number of public employees, and cut back on publically-funded social services. These structural adjustment requirements not only affect women and men differently, but they also depend on women's labor for their fulfillment. Thus, by following Enloe's admonition to take women seriously, we not only recognize the differential effects of policy-level practices on different constituencies but also come to appreciate how women's labor is mobilized and deployed in this new macro-social environment. Here, it may be appropriate to note that while many readers of the JWSR recognize the differential class or race effects of policy reform, they often fail to address the gendered effects of these same reforms.

Enloe's second critical contribution is her understanding of women during periods of recession. Like their counterparts in aid-dependent economies forced to respond to the demands of the International Monetary Fund, reductions in government jobs and cutbacks of social services disproportionately affect women. Enloe uses this finding, and the efforts of the Women's Scholars Forum, a feminist scholars network whose focus is on U.S. federal policy recommendations where women matter, to argue against homogenizing categories. She emphasizes, instead, the criticality of stimulus plans that are cognizant of their impact on different constituencies. Enloe alerts her readers to the worrisome fact that economic anxiety can, and often does, enable misogyny, especially when gender differences are ignored.

Subsequent chapters include a conversation with Cynthia Cockburn, a fellow activist scholar working at the intersection of gender and peace and conflict studies. Here, Enloe reveals the significance of their transnational experience for understanding ongoing efforts to militarize daily life in ways that force women's complicity. In a conversation with Nadine Puechguirbal, another peace studies political scientist who has worked with the United Nations and the International Committee of the Red Cross in Haiti, Enloe reveals the costs of ignoring women in development planning made evident when donors prioritize institutional efficiencies, rather than the needs of families for food and resources. Highlighting how ignorance about women and gender relations results in failed promises and ineffective programs, these chapters promise to 
aid students in understanding relations among development policy, planning, and intervention, and the costs of ignoring women as agents of their lives, their families, and their communities.

The strategic question - when and how should women feature in processes of changecenters Enloe's "dinner party" discussion in the final chapter. Like its counterpart in the revolutionary Sandinista movement of the $1980 \mathrm{~s}$, Enloe argues that gender issues continue to be viewed as subordinate to other forms of economic and social insecurity and in political programs for change. At the dinner party discussion of the post "Arab Spring" uprisings, various women note that "women's issues and women's participation get pushed aside" as male compatriots affirm that they "have to get down to the serious business of constructing a new political system" (p. 166). Also telling in the strategic relationship between real politiks and women's concerns is the idea held by some that "the oppression of women is good for political order" (p. 138). This relation, between gender violence and political order, often implicitly assumed, undergirds policy dialogue and helps to explain the resistance of so many governments to activists who fight against various forms of violence against women, e.g., domestic violence, date, marital, and wartime rape, and sex trafficking.

While these critical themes in Seriously! contribute significantly to asserting that gender differences, micro-dynamics of everyday life, transnational intersections, and institutional politics matter in shaping policy prescriptions and implementation, a critical engagement with the particularities of neoliberalism or the specific character of the current global crisis would have been welcome. In what ways, for example, does the current crisis alter patterns of social inclusion and exclusion in the body politic? How might greater attention to diversity among women explain patriarchal relations and forms of gendered violence? Also important is the recognition that, like many of the programs that were the product of struggles since the $1970 \mathrm{~s}$, feminist and gender studies programs have been at the cutting edge of theory, interdisciplinarity, methodological inventiveness, and foci that explore the everyday worlds of people as well as global processes and transnational relations. Important as well would have been the inclusion of feminist or queer theory critique, rather than a primary focus on gender, which has the effect of treating gender as a dichotomous variable. Omissions of these themes means that while Enloe ably attends to the ways in which gender-neutral arguments ignore women and demasculinize men, her analytic remains within a mainstream political science framework that ignores sexuality and gives scant attention to race and class differences. Thus, while providing the important, and necessary, reminder to take women seriously, Enloe unfortunately misses the opportunity to incorporate insights learned over the past 25 years to offer what she acknowledges as a "feminist-informed gender analysis" (p. 184). Such an analysis would challenge generalized understandings of patriarchy, the contradictions associated with treating women as a homogeneous social category, and the theoretical contributions that have emerged from queer and postcolonial studies over the past thirty years.

Shelley Feldman

Department of Development Sociology, Cornell University rf12@cornell.edu 


\section{David West. 2013. Social Movements in Global Politics. Malden, MA: Polity. 251 Pages, ISBN 978-0745649603 Paper (\$24.95).}

Social movement scholarship is often plagued with binary accounts that present movements and movement outcomes through a lens of either totalizing optimism or postmodern skepticism. David West's book, Social Movements in Global Politics, suffers from neither of these problems. As West reminds us throughout his work, "[b]oth optimism and pessimism are inappropriate reactions to our current situation because the future depends on what we now collectively decide to do" (p. 225). West formulates an activist conception of politics and analyzes the relationship between social movements and political institutions in order to illustrate the power of individual and collective action. West's book seamlessly blends a diverse array of sources, from political philosophy to social movement scholarship to critical theory, in order to highlight the often contradictory ways in which global politics and social movements interact to alter not only the identities of global actors, but the very trajectory of political institutions and world historical forces.

Part I of West's Book, appropriately titled "Foundations," differentiates between institutional and extra-institutional forms of politics. For West, narrowing the focus to institutional politics obscures both the role and the impact of social movements in shaping history. In order to illustrate the numerous ways that social movements have contributed to the creation of contemporary politics, West discusses the important role that extra-institutional politics played in shaping the modern nation-state in Europe and in the creation of the working class in the wake of the industrial revolution. Through his historical sketch, West tackles topics such as the Reformation, the French Revolution, and the bourgeois social movements that arose in response to the broadening and deepening of capitalism. West demonstrates how social movements, especially movements that neglected parliamentary and revolutionary routes to socialism, have been "hidden from history" in an effort to discourage extra-institutional forms of politics (p. 44). West also sets the stage for the emergence of "new" social movements in the late 1960 s that placed less emphasis on economic issues and the importance of state capture as a means to ameliorate injustice.

Part II "Social Movements in Contemporary Politics" explores the rich array of social movements that emerged after WWII, especially the array of movements that privileged issues of race, gender, sexuality, nuclear disarmament and the environment over class issues. West provides brief overviews of the Civil Rights Movement, the counter culture of the 1960s, student radicalism, and the opposition to the Vietnam War before detailing the events of May 1968 in France and, subsequently, the death of the Old Left. Following the 1968 events, West describes how social movements changed on two related levels: "at the level of theory and ideology; and at the practical level of social movements and political events" (p. 70). At the level of theory and ideology, movement actors became increasingly disillusioned with Marxist notions of class conflict and the centrality of proletarian revolution. Activists began to believe that social transformation could only occur by mustering broad coalitions of actors and complementing economic change with cultural alterations of society. Relatedly, movement actors were placing less stock in the role of institutionalized politics, the labor movement, and the need for rigid organization. At the level of social movements and political events, the 1968 events spurred on a wave of movements such as second-wave feminism, sexual liberation movements, gay liberation, and Black Power. 
West emphasizes the role of identity in politicizing both social movement actors and issues previously excluded from the realm of institutional politics. For West, identity politics help to undermine oppression by empowering actors to recognize their own positions of inequality and, as a result, to become liberated from them. The strategy that actors employ to overcome oppression is not only "worthwhile in its own right, it will also help to dislodge institutional and economic forms of subordination as well" (p. 83). The danger of identity politics, however, is that an explicit focus on identity may obscure the role that structural forces play in creating the conditions of oppression in the first place. As West reminds us, "identity politics supplements and enriches, but does not replace other political-legal and economic dimensions of struggle" (p. 77). A further problematic aspect of identity politics, for West, is the potential for social movements centered on issues of identity to fragment as a result of both the transient natures of identities as well as the separatist nature inherent in identity-based movements.

As West's account makes clear, it appears unlikely that we will see a complete revival of labor and materialist social movements. Likewise, although the rise of identity politics has resulted in a plethora of new social movements, the negative aspects of identity politics lead us to question some of the outcomes that such movements have generated. Exploring how autonomous global social movements may coalesce, West posits two potential avenues: the politics of survival and the new politics of exploitation. For West, the politics of survival consists of an amalgamation of the peace, environmental, and green movements. The politics of survival is concerned with traditional questions of contemporary environmentalism - drawn from an array of accounts such as deep ecology, humanistic ecology, eco-capitalism and eco-socialism-as well as a range of issues that are characteristic of new social movements. According to West, the politics of survival combines ecological activism with "commitments to gender equality, the rights of gays, lesbian and other sexual minorities, social equality, participatory or 'grassroots' democracy, international justice, nuclear disarmament and peace" (p. 103). The new politics of exploitation, for West, is an outgrowth of corporate-led neoliberal globalization, which exacerbates inequalities of wealth and power and has led to a downward spiraling of labor and environmental standards across the globe. Like the politics of survival, West illustrates how the new politics of exploitation borrows certain aspects from the ideology and practice of revolutionary socialism and social democracy, but differs from earlier movements in its "selfconscious emphasis on extra-institutional activism within civil society, which it has inherited from earlier waves of activism, including those of the new social movements" (p. 129). Here, West differentiates between spatial globalization and economic globalization and, by extension, the differences espoused by anti-globalization activists and alter-globalization activists. Of course, there are no obvious or automatic solutions to global environmental degradation and the proliferation of neoliberal globalization, but West argues that an adequate response to both requires an energetic global civil society that represents a plurality of issues, that spans the gap between institutional and extra-institutional forms of politics, and that incorporates the ideology and actions of social movements, both new and old.

The final section "Theories of Social Movements" traces the origins and evolution of theoretical accounts of movements and movement politics before offering a critical evaluation and reappraisal of movement theories and positing a new research approach. West traces the development of social movement thought from its earliest period when collective behavior was considered irrational, through to the emergence of resource mobilization, framing, and new social movement approaches. While not as exhaustive as similar accounts (e.g. Piven and 
Cloward 1977; McAdam 1982) his summary is succinct enough to explain the "normative shift" that took place in the social sciences with "attempts to explain the distinctive rationality of collective action as demonstrated by successful social movements" (p. 153, emphasis in original). Even after the normative shift occurred, however, West argues that social movement scholarship was dominated by "formal approaches" which "focus on those features of extra-institutional politics that distinguish social movements generally from institutionalized and organized forms of politics" (p. 172). The problem, for West, is that formal approaches are unable to live up to their lofty expectations of explanatory models, as they are overly concerned with conceptualizing more and more nuanced features of social movements.

In an effort to strike a path forward, West concludes his book by suggesting some foundational principles for a critical theory of social movements. West's recommendations in this regard attempt to toe the line between "dogmatic" theories of society and "unhelpful postmodern sceptisim" (p. 201). In the tradition of the Frankfurt School, West sees a critical theory of social movements as one that renounces totalizing accounts of society and blueprints for social movement action. Instead, the critical theorist "should be committed to acknowledging multiple perspectives, experiences and voices. Theory should provide a 'political toolbox' for social movements" (p. 203). In this sense, however, a critical theory should not necessarily seek to provide tools to already politicized actors but, instead, should allow individuals to recognize the emancipatory potential of their own actions. Although a critical theory of social movements should reject totalizing accounts of society and recognize the plurality of voices and experiences, West argues that "we have no choice but strive for some kind of agreement around normative framework and knowledge of reality" (p. 217). West closes with "a few speculative and sketchy remarks" on what a common framework might look like. West's argument is grounded in his earlier discussions of the concept of nature and green ideology. He readily admits, however, that environmental ideas and green ideology are results of historical factors, and, as such, there is no reason to expect that a normative concept of nature can provide a basis for contemporary social movements. That said, West does see the concept of nature as compatible with a diverse array of movement goals and one that can successfully incorporate both new social movements and classical materialist and economic concerns.

If there is a blind spot in West's analysis, it is his failure to incorporate any discussion of the World Social Forum (WSF) into his empirical account. In his analysis of the problems associated with the current path of neoliberal globalization and the potential ameliorative effects of social movements, West argues that "[a]n adequate response to corporate globalization requires... a more active, expansive and powerful global civil society." The omission of the WSF, therefore, is surprising, not only because the WSF represents perhaps the most burgeoning global civil society, but, as Smith and Wiest (2012) have argued, it is one of the most important political developments of the new millennium. Given the focus of his book on social movements and global politics, he misses an excellent opportunity to apply his critical theory of social movements to a global coalition of autonomous movement actors. West's neglect of the WSF is even more mystifying given his affinity for using the WSF's slogan "another world is possible," and the fact that he describes in lucid detail numerous antecedents of the WSF and the changing global processes that, in substantive ways, informed the WSF's formation and organizational structure.

Another criticism of the text is that, in some ways, West fails to apply the research approach he lays out in his concluding chapter to the movements that he summarizes earlier in the text. For example, West's discussions of the Civil Rights and feminist movements are 
largely orthodox accounts that extoll the benefits of these movements without critically evaluating the gains made. It would have been interesting to see West engage with the existing critical theories of these movements, such as Bell's (1992) reassessment of the Civil Rights movement or Fraser's (2013) critique of second wave feminism, in order to illustrate how a critical theory of social movements is useful not only for orienting the study of future movements, but also for reconsidering movements of the past. The book also suffers from some degree of Western bias. This is not to say that West ignores movements and politics that occur in peripheral and semi-peripheral states, but that he goes into substantive detail describing movements in core countries while providing only cursory reference to movements and politics in the Global South.

These criticisms notwithstanding, West has written an excellent book. Social Movements in Global Politics is accessible enough to function as an introductory text to social movements, yet remains rich with West's interpretation of the nuances of political philosophy, global politics, and critical theory. West concludes each chapter with assessments and critiques that present readers with a plurality of views, and his extensive bibliography and recommendations for further reading illuminate a robust literature. West's book is an invaluable addition to social movement scholarship, and his formulation of a critical theory of social movements will provoke discussion for years to come.

\section{References}

Bell, Derrick. 1992. Faces at the Bottom of the Well: The Permanence of Racism. New York: Basic Books.

Fraser, Nancy. 2013. Fortunes of Feminism: From State-Managed Capitalism to Neoliberal Crisis. Brooklyn, NY: Verso.

McAdam, Doug. 1982. Political Process and the Development of Black Insurgency, 1930-1970. Chicago: University of Chicago Press.

Piven, Frances Fox and Richard Cloward. 1977. Poor People's Movements: Why They Succeed, How They Fail. New York: Vintage Books.

Smith, Jackie, and Dawn Wiest. 2012. Social Movements in the World System: The Politics of Crisis and Transformation. New York: Russell Sage Foundation.

Zachary McKenney

Department of Sociology, University of Tennessee-Knoxville

zmckenne@utk.edu 
Kojin Karatani. 2014. The Structure of World History: From Modes of Production to Modes of Exchange. (Trans. by Michael K. Bourdaghs). Durham, NC: Duke University Press. 352 pages, ISBN 978-0822356769 Paper (\$22.98).

The lived experience of twenty-first century globalization urges academics to provide a more cosmopolitan view of the long-term history of humanity. Scholars have embraced this challenge in different ways. The universalist approach of 'big history' looks all the way back to the Big Bang, seeking to integrate human knowledge across natural sciences, social sciences, and the humanities. Comparatively particularistic histories trace the global movement of specific ideas, objects, diseases, human populations and individuals that have moved across borders and continents. Both these framings of global history challenge old narratives of the 'rise of the west,' comparisons of 'world civilizations,' and histories of 'independent' nation-states. They avoid compartmentalized contrasts between us and them, the west and the rest, the developed and underdeveloped. This new consciousness seeks to envision world history as connected, crisscrossed, and entangled. This is not an easy task. Many of these efforts have been accused of being reductionist, selective, eclectic or teleological.

Karatani's The Structure of World History avoids those pitfalls by approaching world history through a carefully selected set of working concepts. Originally published in Japanese in 2010, this is the fifth of Karatani's books to be introduced to the Anglophone world. Trained as a literary critic, Karatani earned wider notice beyond Japan with the translation of his Transcritique: On Kant and Marx. In that book, he articulated a theoretical model that recognizes Capital, Nation and State as a trinity (i.e. Borromean knot), rejecting the image of Capital as base with Nation and State as mere superstructure. In his more recent book, he extends on this insight through a discussion of world history, shifting from Marx's concept of 'mode of production' to that of a broader 'mode of exchange.' The concept of 'exchange' in his model is defined as intercourse or traffic (Germany: Verkher) in a general sense. Marx uses this term frequently in The German Ideology to describe various kinds of exchange relations within and between communities, such as sharing, trade and war. In that text, Marx lays out his ontological theory of history, namely that the very existence of humanity is based on humans' exchanges with nature (metabolism, Stoffwechsel) and with other humans (intercourse, Verkher). Drawing from this early work, Karatani invites us to move beyond Marx's Capital, which dealt only with this one form of intercourse as defined by commodity exchange. Karatani proposes four major types of exchange: reciprocity (Mode A), plunder-redistribution (Mode B), commodity exchange (Mode C), and association (Mode D). These modes of exchange can be differentiated as either reciprocal or non-reciprocal, and as either free or unfree (see the table below). Only the first three modes have predominated in particular periods of human history thus far. For Karatani, the last one is proposed as a "regulative idea."

\begin{tabular}{|l|l|l|}
\cline { 2 - 3 } \multicolumn{1}{c|}{} & Non-Reciprocal & Reciprocal \\
\hline Unfree & $\begin{array}{l}\text { B: plunder-redistribution } \\
\text { [world-empire }]\end{array}$ & $\begin{array}{l}\text { A: reciprocity / gift-return } \\
{[\text { mini-system }]}\end{array}$ \\
\hline Free & $\begin{array}{l}\text { C: commodity exchange } \\
{[\text { world-economy] }}\end{array}$ & $\begin{array}{l}\text { D: Association } \\
{[\mathrm{X}]}\end{array}$ \\
\hline
\end{tabular}


In many ways, these modes of exchange correspond to Polanyi's forms of integration, i.e. reciprocity, redistribution, money-making and house-holding. This book is clearly informed by Polanyi's work, and a related body of archaeological and anthropological studies. However, Karatani's modes of exchange differ from the theoretical typology of human economies that Polanyi puts forth as alternatives to the self-regulating market. Without burdening himself with the critique of capitalism, Karatani substantiates these forms on their own terms. He explains these social formations with lucid theoretical reasoning, and draws from a broad historical and geographical canvas to illustrate them.

In this model, the concept of reciprocity in Mode $\mathrm{A}$ is more than just a simple idea of gifting and counter-gifting out of goodwill. Drawing from Sahlins, Karatani emphasizes that gifting, potlatch and blood vendetta are forms of reciprocity that prevail in clan-based societies. These mechanisms all have a similar levelling effect, preventing the concentration of power and the institution of a hierarchical state. Karatani characterizes this mode of exchange as reciprocal but also unfree, since individuals and sub-groups are bound by communal obligations. In cases where distinct communities are tied together through fictive brotherhood or confederation, he draws from world-system analysis and relates this mode of exchange to the concept of 'minisystems.'

Mode $\mathrm{B}$ or plunder-redistribution is characterized by non-reciprocal and unfree relations of vertical exchange. Drawing from Hobbes, Karatani argues that the institution of the hierarchical state emerges through the conquest of sedentary communities by an external power, i.e. when the act of pillage is further institutionalized into a permanent plunder. This mode of exchange reaches its most advanced form when intermediate powers (e.g. feudal lords or priests) are marginalized through the centralization of imperial power. Such bureaucratic and despotic power was realized historically in many 'Asiatic' states or 'world-empires' (e.g. Egypt, Russia, Mesopotamia, China, India). This did not arise in Greece and Rome where city-states and sedentary communities continued to share power without formal centralization. Drawing from Wittfogel's triad of core, sub-margin and margin, Karatani argues that the formation of feudalism in Europe and Japan can be explained by the geopolitical position of these regions at the sub-margin of world-empires.

The despotic power of world empires constrained the development of mode C, i.e. the exchange of commodities through money. For Karatani, the root form of Mode C (i.e. trade and markets) has existed alongside the other two modes throughout human history. Many archaeological studies have shown that either barter trade or trade with specified monetary objects was a common practice between two communities, in particular on the edges of worldempires. In fact, empire-states often depended on market mechanisms to facilitate the process of redistribution within vast imperial territories. Minting sovereign coins and promoting their circulation through taxation makes it easier for the state to mobilize provisions and materiel. This is not yet a full expression of Mode $\mathrm{C}$, as it remains fully subsumed to the empire-state.

Mode $\mathrm{C}$ advances further only in the sub-margins of world-empire. Where state monopoly and redistribution power is weak, trade competition and war-making are more prevalent. Europe, where maritime city-states remained partly autonomous from Roman rule, proved an especially suitable environment for Mode C. The emergence of absolutism, an alliance between the despotic state and merchant capital, represents the historical reconciliation of Mode $\mathrm{B}$ and Mode $\mathrm{C}$. Their cooperation eventually transformed world history by drawing from the abundant resources of the Americas. The global circulation of precious metals as world-money 
eventually unified the global regimes of value, making possible a singular world-economy composed of sovereign nation-states.

This full penetration of a money economy ultimately marginalizes both Mode $\mathrm{A}$ and Mode B, by freeing individuals from communal obligations and allowing the rise of a bourgeoisie able to resist arbitrary plunder by the state. In this way, Karatani argues that Mode C is 'freed' from communal obligations and state despotism. However, the unlimited accumulation of money, in contrast to limited accession of social status in Mode A, creates an unprecedented class society constituted by the non-reciprocal relation between money owners and commodity owners. Mode $\mathrm{C}$ therefore represents the age of capital as we know it.

Lastly, without concrete historical references, it is difficult to imagine the embodiment of Mode D, which is both reciprocal and free. Karatani refers to this potential form of associationalism simply as " $\mathrm{X}$ ", a regulative idea - rather than as a political blueprint of the kind that inspired communist revolutions from the second half of $19^{\text {th }}$ century. To him, a world beyond capitalism would be a world in which the reciprocity of Mode $\mathrm{A}$ is reconstituted in a higher dimension (i.e. the return of the repressed) retaining individual freedom. According to Karatani, a closely related form of intercourse emerged among nomadic hunter-gatherer peoples before the sedentary revolution, when pooling and the sharing of captured spoils was the dominant mode of exchange. The sparse density of human population allowed members of nomadic groups the freedom to exit the community and avoid communal obligations or hierarchical state plunder. As these societies relied heavily on the abundance of nature, magic and animistic religions played crucial roles in regulating the exchange between human and nature. Speculating on a future expression of Mode D, Karatani looks to the potential role of world religion as a means of realizing Kant's universal moral principle, i.e. for each man to treat every other man as an end in himself, not as a means to an end.

Overall, Karatani not only provides a solid theoretical account of each mode of exchange, but also suggests a structure of world history. The social formations of different historical periods and geographies involve specific articulations of these modes of exchange. By constructing a simple but powerful multivalent model, he provides an alternative to existing theoretical explanations of the origin of the modern capitalist world. He transcends the dispute between Eurocentric and Sino-centric approaches widely debated since the publication of Pomeranz's (2001) The Great Divergence. In place of a singular conception of development, Karatani envisions a truly world-historical perspective. Moreover, his unique approach to world history demonstrates the value of establishing a more constructive dialogue between philosophy, anthropology, sociology, economics and historical studies. I would suggest that we can carry his integrated approach further in two ways. On the one hand, we should examine the validity of this theoretical model through further empirical studies. On the other, we should continue to develop a more concrete vision of Mode D by exercising our sociological imagination in reference to the constitutive elements of Mode A (e.g. patriarchy, patrimony, clan, caste, house-holding). Karatani allows us to rethink these concepts, not as mere pre-modern vestiges, but as a basis for analyzing the substantive possibilities of Mode D. 


\section{References}

Karatani, K. 2005. Transcritique: On Kant and Marx (Trans. by S. Kohso). Cambridge: MIT Press.

Pomeranz, K. 2001. The Great Divergence: China, Europe, and the Making of the Modern World Economy. Princeton: Princeton University Press.

Yamoi Pham

Department of Sociology, Binghamton University ypham1@binghamton.edu 